\title{
Impacts of Climate Variability and Human Activities on the Changes of Runoff and Sediment Load in a Catchment of the Loess Plateau, China
}

\author{
Peng Tian, ${ }^{1}$ Xingmin $\mathrm{Mu}^{2,3}$ Jianli Liu, ${ }^{4}$ Jinfei $\mathrm{Hu}^{2,3}$ and Chaojun $\mathrm{Gu}^{2,3}$ \\ ${ }^{1}$ College of Resources and Environment, Northwest A\&F University, 3 Taicheng Road, Yangling, Shaanxi 712100, China \\ ${ }^{2}$ State Key Laboratory of Soil Erosion and Dryland Farming on the Loess Plateau, Northwest A\&F University, \\ Xinong Road 26, Yangling, Shaanxi 712100, China \\ ${ }^{3}$ Institute of Soil and Water Conservation, Chinese Academy of Sciences \& Ministry of Water Resources, 26 Xinong Road, \\ Yangling, Shaanxi 712100, China \\ ${ }^{4}$ Wuqi Water Conservancy Team, Wuqi County, Shaanxi 717600, China
}

Correspondence should be addressed to Xingmin Mu; xmmuiswc@gmail.com

Received 7 June 2016; Revised 28 August 2016; Accepted 14 September 2016

Academic Editor: Roberto Fraile

Copyright (c) 2016 Peng Tian et al. This is an open access article distributed under the Creative Commons Attribution License, which permits unrestricted use, distribution, and reproduction in any medium, provided the original work is properly cited.

\begin{abstract}
The objectives of this study are to investigate the changes of runoff and sediment load and their potential influencing factors in the Huangfuchuan catchment. The Mann-Kendall test and accumulative anomaly methods were, respectively, applied to examine the changing trends and abrupt changes. Both annual runoff and sediment load demonstrated significant reduction $(p<0.05)$ with decreasing rates of $-3.2 \times 10^{6} \mathrm{~m}^{3} / \mathrm{a}$ and $-1.09 \mathrm{Mt} / \mathrm{a}$, respectively. The abrupt changes were detected in 1979 and 1996 for the runoff and sediment load. All the runoff and sediment indices (runoff, sediment load, runoff coefficient, and sediment concentration) exhibited remarkable reduction $(p<0.01)$. The climate variability contributed $24.4 \%$ and $25.1 \%$ during $1980-1996$ and $1997-2010$ to annual runoff decrease, respectively, and human activities accounted for the remaining $75.6 \%$ and $74.9 \%$. In contrast, changes in precipitation accounted for $43.5 \%$ and $20.2 \%$ of sediment load reduction during 1980-1996 and 1997-2010, whereas the human activities contributed $56.5 \%$ and $79.8 \%$, respectively. The relative contributions from climate variability and human activities to runoff and sediment load changes at annual scale were different from that at flood season scale. Results suggested the dominant role of soil and water conservations in the variation of runoff and sediment load in the catchment.
\end{abstract}

\section{Introduction}

Climate change and intensive human activities have greatly altered the regimes of runoff and sediment transportation in river systems throughout the world [1-4]. Changes in fluvial hydrological regimes may lead to evident variation in geological, biological, and chemical processes, which largely influence the geomorphology of land surface, river channels, floodplains, and deltas [5-7]. Furthermore, the global human demand for renewable water resource has increased rapidly due to the increasing population and economy development, and many regions in the world have experienced severe water stress [8-10]. It is of particular importance to investigate the historical changes of runoff processes and sediment transport for river basin management and water resources management.

It has been reported that apparent decreasing and increasing trends were detected in runoff and sediment load in many rivers around the world $[3,7,11-14]$. Walling and Fang [15] assessed the variations of runoff and sediment load at the furthest downstream gauging stations of 145 world rivers. They found that the rivers with decreasing runoff and sediment load accounted for $22.5 \%$ and $47.9 \%$, respectively. More than half of the rivers showed stable runoff and sediment load. In China, many recent publications have documented variations of runoff and sediment load in different rivers over the last half century on the basis of continuous records at mainstream stations as well as in the 
tributaries [16, 17]. Together, these studies gave a detailed view of the rapid decline in runoff and sediment flux in the basins as a result of intensive human activities (e.g., agricultural irrigation, soil and water conservation measures, and dams construction) [16, 18-22].

However, most of these studies investigated the spatialtemporal variation of runoff and sediment load at annual scale; only a few were undertaken at other temporal scales for different objectives. The investigations through different temporal scales may provide useful insights for implementation of river basin management. For example, Warrick and Rubin [23] examined the changes in suspended sediment concentrations in Santa Ana River, California, and found a decrease of 20-fold with respect to runoff, while the annual peak and total runoff reveal sixfold increases. A nonlinear dilution process explained the decreases in sediment concentration. Komatsu et al. [24] addressed that no significant increase in frequencies of high peak flow with decreased forestry practices was detected in a small watershed in Japan, and the increase in flood risk might be less than expected.

The Chinese Loess Plateau is located in the upper and middle reaches of the Yellow River, covering an area of 0.63 million $\mathrm{km}^{2}$. The region has suffered severe soil erosion over the past thousands of years that led to serious land degradation of the Loess Plateau. It has been estimated that the average annual erosion modulus for the region ranges from 5000 to $10000 \mathrm{t} / \mathrm{km}^{2}$. Severe soil erosion has led to the impoverishment of arable land and to desertification [25-27]. Currently, more than $70 \%$ of the area is dominated by gullyhill topography due to massive soil erosion [28]. Precipitation is characterized by high variability at spatiotemporal scale and mostly concentrated within the summer season. The Loess Plateau contributed approximately $90 \%$ of the sediment on average to the Yellow River $[29,30]$. In recent decades, the mean annual runoff and sediment load of the Yellow River have declined markedly due to reduced precipitation, increased water withdrawal, and the implementation of soil and water conservation and dams' construction $[10,16,31-$ 33].

As aforementioned, a number of studies focused on the changes of runoff and sediment load at annual scale on the Loess Plateau, but there were few studies on seasonal or daily scales $[4,29,34-37]$. In fact, most of the runoff is generated during rainy season with a few intense storm events in the Loess Plateau. A large proportion of sediment load was observed during relatively short-duration floods [38]. Therefore, it is critical to examine the variations of hydrological time series to reveal the dynamics of runoff and sediment transport at multitemporal scales, which may provide better understanding of changes in hydrological regimes for watershed management. The objectives of this study are to investigate the changes of runoff and sediment load in the Huangfuchuan catchment at multitemporal scales and to quantify the contributions of climate variability and human activities on runoff and sediment load changes.

\section{Study Area and Data}

2.1. Study Area. This research is conducted in the Huangfuchuan River catchment (Figure 1), located in the middle reaches of the Yellow River. The whole catchment covers an area of $3,246 \mathrm{~km}^{2}$. The river originates in the Southern Inner Mongolia, flows through the southeastern Ordos Plateau, and discharges into the Yellow River in Fugu County of Shaanxi Province. The river system within the catchment comprises two main tributaries: Nalin and Changchun Rivers. The Huangfu station is the final hydrological station in the Huangfuchuan River.

The catchment lies in the semiarid zones with average annual precipitation and temperature being approximately $380 \mathrm{~mm}$ and $7.5^{\circ} \mathrm{C}$, respectively [39]. More than $70 \%$ of the annual precipitation falls between June and September, mainly as intense storms (1965-2010). Consequently, runoff is concentrated in the rainy season $[40,41]$.

The catchment belongs to coarse sandy region and is mainly covered by silty loess, sand, and weathered sandstone (Pisha stone). It consists of a dense network of gullies, with very sparse vegetation. Through field survey, the bare weathered sandstone on the steep gullies was the dominant sediment source, accounting for approximately $70 \%$ of total sediment yield. Average annual sediment yields were higher than $110 \mathrm{t} / \mathrm{ha} / \mathrm{a}$ according to check dam sedimentation, suggesting extremely high soil erosion rates in the study area [42]. Since the 1950s, a series of soil and water conservation measures have been implemented in the catchment, such as terraces, check dams, and reservoirs. In 1999, the Chinese government launched a great ecological restoration project "Grain to Green," leading to evident changes in vegetation cover in gentle slopes of the study area [10]. Based on the interpreted land use map from Landsat images in 2006 [43], the dominant land use/cover were grassland $\left(2528.6 \mathrm{~km}^{2}\right.$, $77.9 \%)$, bare/unused land $\left(345.5 \mathrm{~km}^{2}, 10.6 \%\right)$, and arable land $\left(223.12 \mathrm{~km}^{2}, 6.9 \%\right)$. Due to limited area of arable land, agricultural irrigation had negligible effects on runoff changes. Thus, we did not consider the effects of irrigation on runoff and sediment load changes in the study area.

2.2. Dataset. The daily runoff, sediment load, and sediment concentration data (1965-2010) at the Huangfu hydrological station with controlled area of $3,175 \mathrm{~km}^{2}$ were obtained from the Hydrology Bureau, Yellow River Conservancy Commission, China. Daily precipitation from 1965 to 2010 at 5 gauge stations inside the catchment was also collected from Hydrological Yearbook of the Yellow River. Another 6 rainfall gauges started observation since 1976. All the precipitation time series were interpolated by Inverse Distance Weighted (IDW) method to obtain the basin-average monthly and annual precipitation. The daily climate data at Hequ station were obtained from Chinese Climate Centre. Figure 1 shows the locations of the hydrological, rain gauge, and climate stations. All the measured data were checked by the corresponding agencies to guarantee the data quality.

We selected several indices at different scales to fully understand the changes of runoff and sediment load. The 


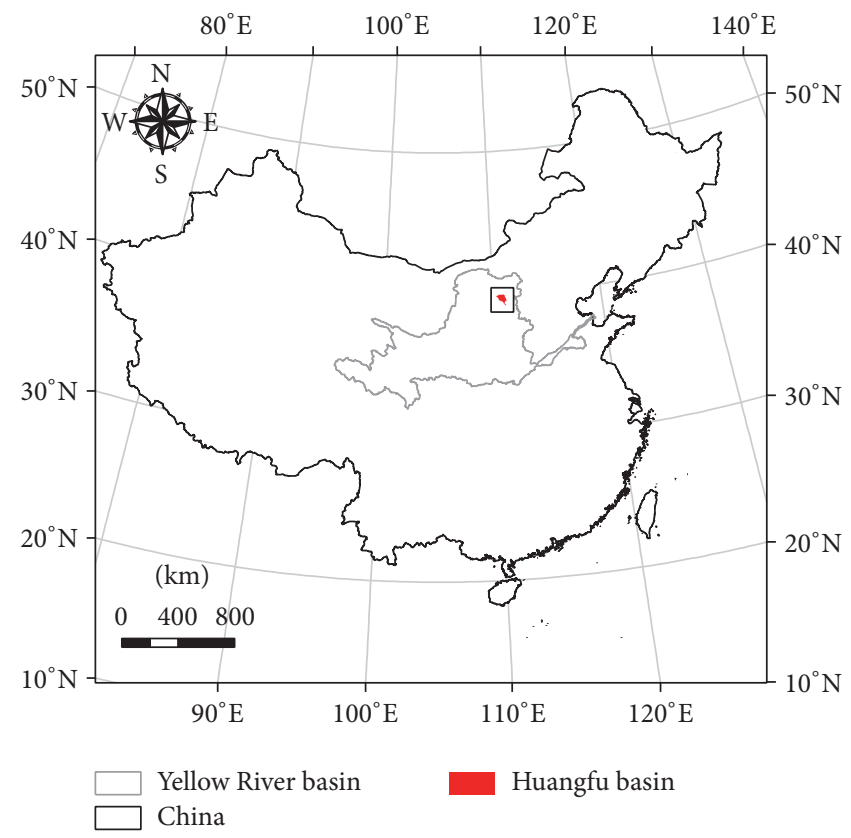

(a)

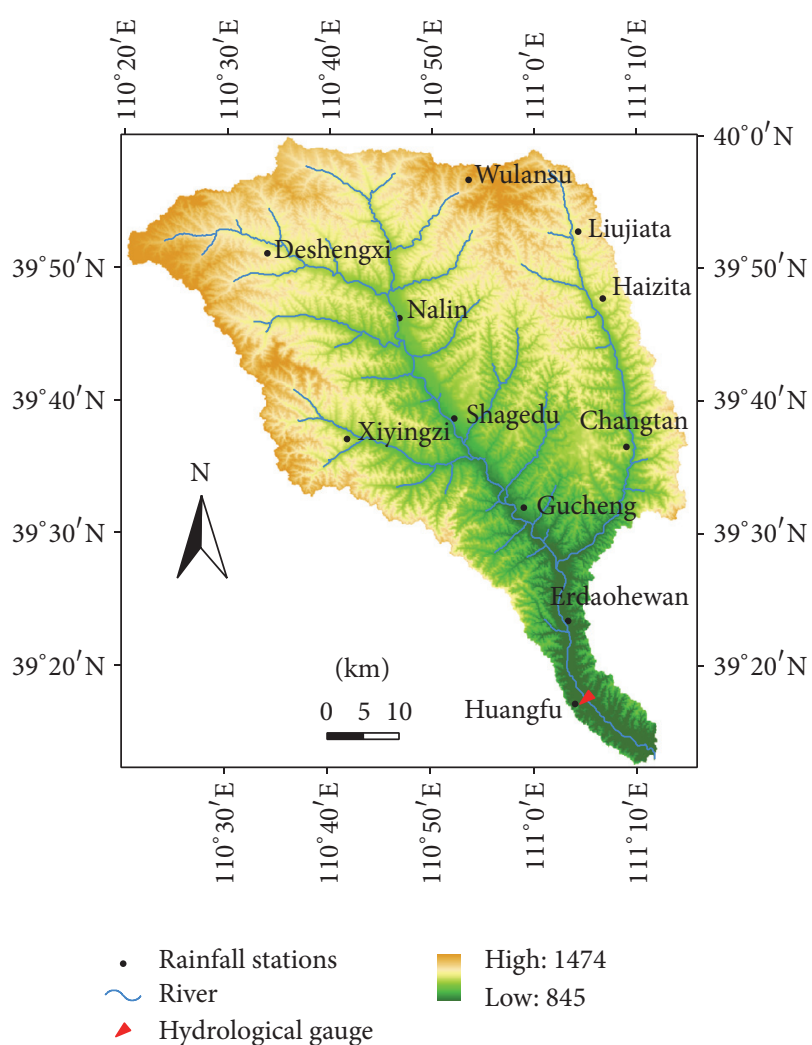

(b)

FIgURE 1: Location of the study area on the Loess Plateau, China ((a) map of China with study area; (b) location of study area with precipitation stations, hydrological gauge).

runoff $\left(Q, \mathrm{~m}^{3}\right)$, sediment load (Sed, $\left.\mathrm{t}\right)$, runoff coefficient $(\mathrm{Cr}$ $\%)$, and sediment concentration $\left(\mathrm{SC}, \mathrm{kg} / \mathrm{m}^{3}\right.$ ) were selected for investigation at annual, flood season, and monthly scale. According to climate pattern and runoff data, the flood season is from May to October. Cr denotes runoff availability per unit area per unit precipitation in the catchment within a specific period. It can be calculated as

$$
\mathrm{Cr}=\frac{Q}{1000 \cdot P \cdot A}
$$

where $Q$ is runoff $\left(\mathrm{m}^{3}\right)$ and $P$ and $A$ denote annual precipitation $(\mathrm{mm})$ and catchment area $\left(\mathrm{km}^{2}\right)$. In addition, the maximum daily runoff $\left(\mathrm{m}^{3} / \mathrm{s}\right)$, sediment discharge $(\mathrm{t} / \mathrm{s})$, and sediment concentration $\left(\mathrm{kg} / \mathrm{m}^{3}\right)$ were chosen as the hydrological variables on the daily scale.

\section{Methodology}

3.1. Mann-Kendall Test. The nonparametric Mann-Kendall test method was applied to examine hydroclimatic time series trends $[44,45]$. The method has been widely used to detect trends in hydrometeorological time series in different regions throughout the world [33, 46, 47]. Given a specific time series
$X\left(x_{1}, x_{2}, \ldots, x_{n}\right)$ with the length of $n$, the statistic $S$ is defined as

$$
\begin{array}{r}
S=\sum_{i=2}^{n} \sum_{j=1}^{i-1} \operatorname{sgn}\left(x_{i}-x_{j}\right), \\
\operatorname{sgn}\left(x_{i}-x_{j}\right)= \begin{cases}1 & x_{i}>x_{j} \\
0 & x_{i}=x_{j} \\
-1 & x_{i}<x_{j},\end{cases}
\end{array}
$$

where $x_{i}$ and $x_{j}$ are the sequential data values and $i$ is greater than $j$. Mann [45] and Kendall [44] addressed that the statistic $S$ is approximately normally distributed, and the variance is calculated as

$$
\operatorname{var}(S)=\frac{n(n-1)(2 n+5)}{18} .
$$

The standardized statistic is

$$
Z= \begin{cases}\frac{(S-1)}{\sqrt{\operatorname{var}(S)}} & S>0 \\ 0 & S=0 \\ \frac{(S+1)}{\sqrt{\operatorname{var}(S)}} & S<0 .\end{cases}
$$


A positive or negative value of $Z$ indicates an upward or downward trend, respectively. The null hypothesis $H_{0}$ is rejected if $|Z|<Z_{(1-\alpha / 2)}$ indicating a statistically significant trend in the time series at the significance level of $\alpha$.

This method does not assume a specific distribution for the data, and it is not sensitive to outliers. To eliminate the effects of the serial correlation on the MK test, the trend-free prewhitening procedure was used to remove the effects of serial correlation [47]. Autocorrelation coefficients analysis suggested that the hydrological time series are time independent.

The trend magnitude can be estimated by a nonparametric median based slope method, which was proposed by Sen [48] and extended by Hirsch et al. [49]:

$$
\beta=\operatorname{Median}\left[\frac{x_{j}-x_{k}}{j-k}\right],
$$

where $1<k<j<n$ and $\beta$ is the median of all the possible combinations of pairs for the entire dataset.

3.2. Accumulative Anomaly Test. The accumulative anomaly method is a direct nonlinear test approach to examine the abrupt changes of hydroclimatic time series. For a given time series of $X_{i}\left(x_{1}, x_{2}, \ldots, x_{n}\right)$, the accumulative $X_{k}$ can be calculated as

$$
X_{k}=\sum_{i=1}^{k}\left(x_{i}-\bar{x}\right), \quad k=1,2, \ldots, n,
$$

where $\bar{x}$ is the mean value of time series and can be estimated as

$$
\bar{x}=\frac{1}{n} \sum_{i=1}^{n} x_{i}
$$

The accumulative anomaly $X_{k}$ can be used to assess the fluctuation magnitude of the time series. The positive or negative values signify that the corresponding data points are higher or lower than the average. According to the evident changes in the slope of the accumulative values, the abrupt changes can be detected in the related time series [37].

\subsection{Impact of Climate Change and Human Activity on Runoff} and Sediment Load. The double mass curve is a plot of the accumulative values of one variable against the other for the same period. It is a practical method to identify the hydrological regime changes caused by anthropogenic intervention [46]. The double mass curve can be plotted as a straight line when two variables are proportional, and the slope of this line represents the constant of proportionality between the two variables. It can be applied to identify the consistency and relationships between two hydrological or climatic variables [32].

In this study, we applied the double mass curve method of runoff/sediment load versus precipitation to detect the effects of climate change and human activities on runoff and sediment load variations. The linear regression equations between the accumulative runoff/sediment load and precipitation before the abrupt changing points were established.
The average runoff and sediment load after the transition year without effects of human activities can be estimated through the established regression equations and precipitation. The differences between the estimated and observed runoff and sediment load after the change point were considered to be the effects of human activities and the remaining was related to the climate change.

\section{Results}

4.1. Variation of Runoff and Sediment Load at Annual and Seasonal Scales. As shown in Figure 2, the monthly sediment load at Huangfu station shows a strong consistency with the runoff distribution, as characterized by the coincidence of high sediment load and runoff during the rainy season. The runoff and sediment load between July and August were 0.08 $\times 10^{9} \mathrm{~m}^{3} / \mathrm{a}$ and $33.14 \mathrm{Mt} / \mathrm{a}$, accounting for $71.4 \%$ and $90.0 \%$ of the annual total (1965-2010), respectively.

Figures 3(a) and 3(b) show the temporal changes of annual runoff and sediment load at Huangfu station between 1965 and 2010. It can be clearly seen that significant decreasing trends at 95\% confidence level were detected in both annual runoff and sediment load with average reduction rates of -3.2 $\times 10^{6} \mathrm{~m}^{3} / \mathrm{a}$ and $-1.09 \mathrm{Mt} / \mathrm{a}$, respectively (Table 1). Average annual runoff was $0.167 \times 10^{9} \mathrm{~m}^{3} /$ a within $1965-1969$, while it was only $0.033 \times 10^{9} \mathrm{~m}^{3} / \mathrm{a}$ from 2000 to 2010 , accounting for approximately $20.0 \%$ of that in the previous period. In contrast, average annual sediment load was 8.83 million $t$ during 2000-2010, only $15.3 \%$ of the annual total between 1965 and 1969.

According to the accumulative anomaly test results, the annual and flood season hydrological variables showed nearly the same changing points. All of the abrupt change points were statistically significant $(p<0.05)$. Figures 3(c) and $3(d)$ show the abrupt changes in annual runoff and sediment load. The fluctuation of the curves presented three individual phases for annual runoff and sediment load. An increasing trend can be clearly seen between 1965 and 1979 due to positive slope of the curve. Within the period of 1997 to 2010, both of the records illustrated an evident reducing trend.

Table 1 shows statistics of Q, Sed, SC, and Cr at the annual and flood season scales during 1965-2010. The mean runoff $Q$ in the flood season was $0.10 \times 10^{9} \mathrm{~m}^{3}$, accounting for approximately $89.7 \%$ of the annual total. Similarly, most of the sediment load occurred in the flood season, accounting for $99.8 \%$ of the annual total. The average suspended sediment concentration in flood season was $318.7 \mathrm{~kg} / \mathrm{m}^{3}$ and was slightly higher than the average annual SC.

The MK test indicated significant decreasing trends of Q, Sed, SC, and Cr on both annual and flood season scales, particularly for the runoff coefficient. The flood season runoff had the decreasing rates of $2.6 \times 10^{6} \mathrm{~m}^{3} / \mathrm{a}$, which was lower than the annual changing rate. The sediment load showed nearly the same decreasing rate ( 1.1 million t/a) at annual and flood season scales. However, the SC decreased more rapidly in the flood season than the changes of annual SC. The changing rate of annual $\mathrm{Cr}$ is a little higher than that in the flood season. 


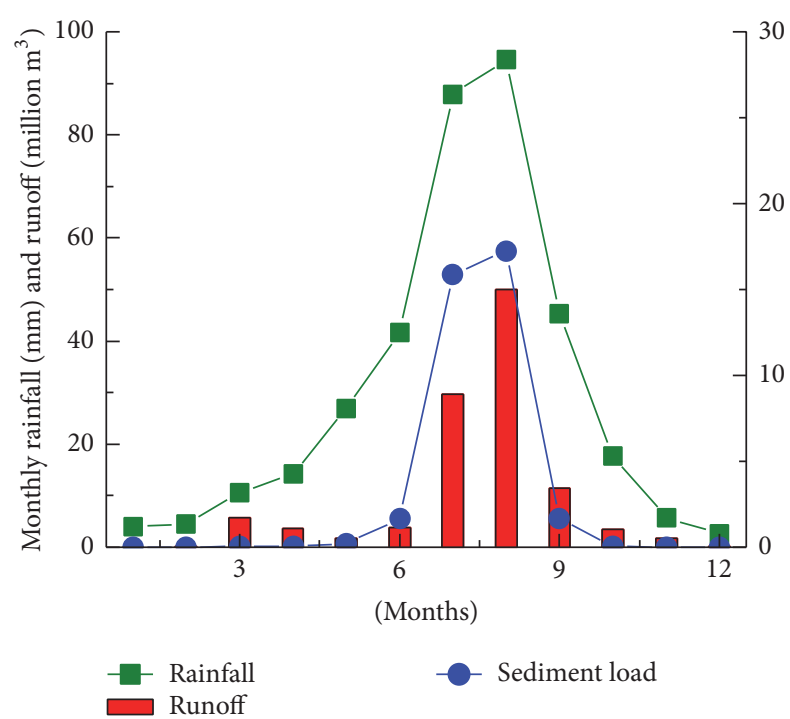

(a)

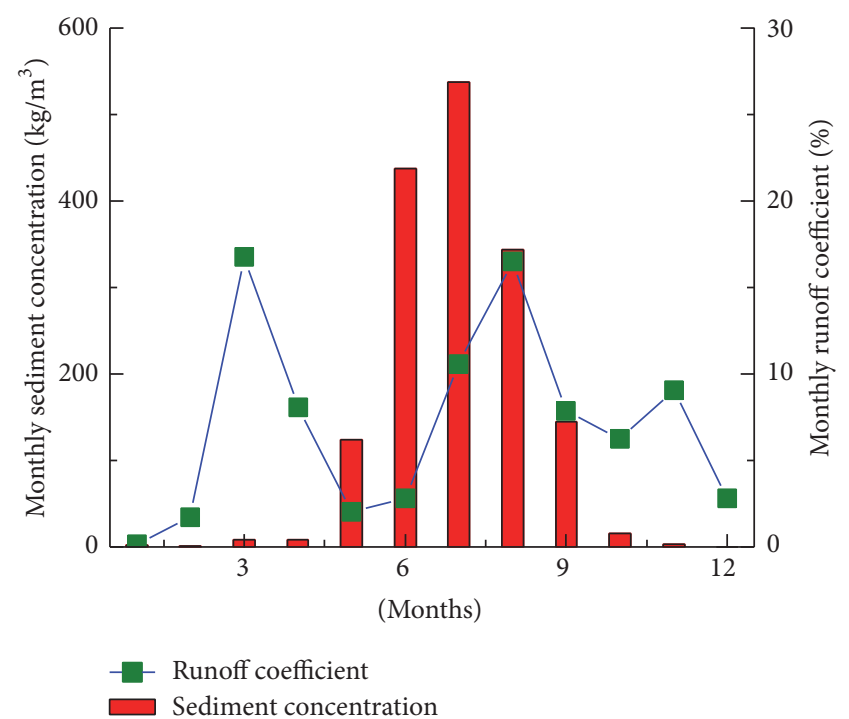

(b)

Figure 2: Monthly mean runoff and sediment load at Huangfu station ((a) monthly precipitation, runoff, and sediment load; (b) monthly runoff coefficient and sediment concentration).

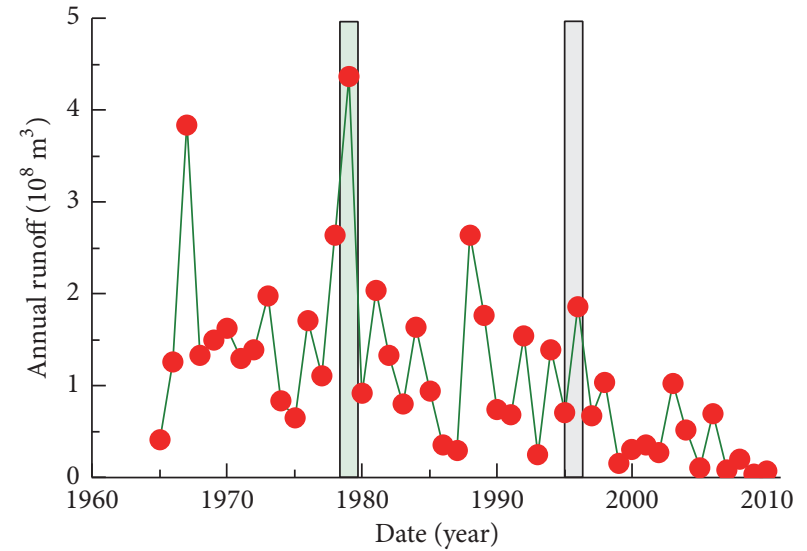

(a)

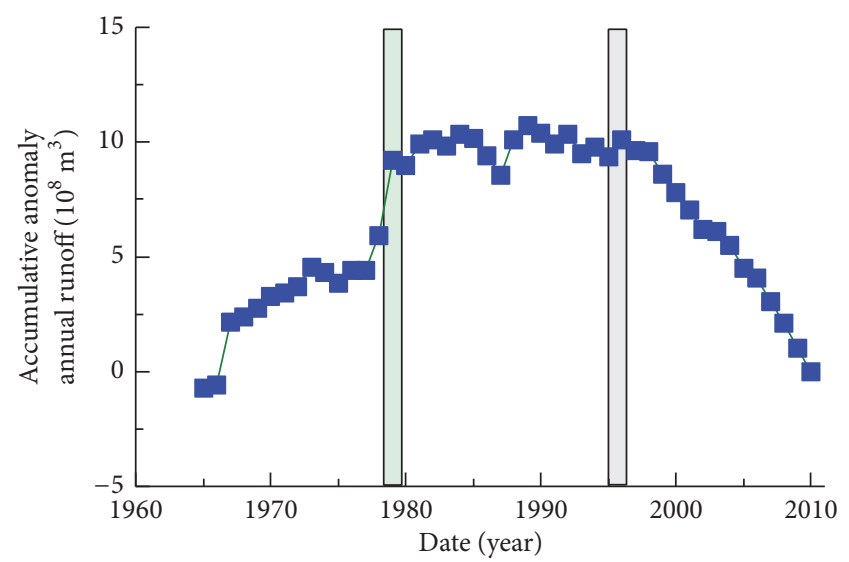

(c)

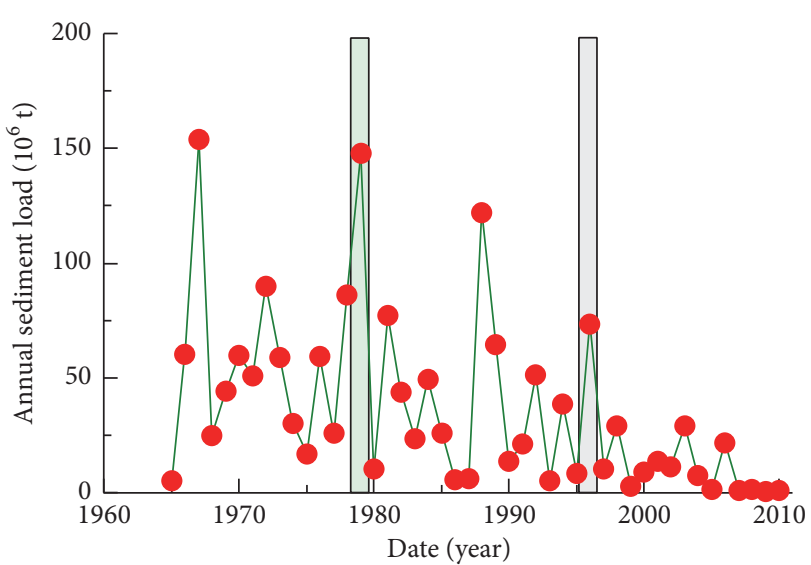

(b)

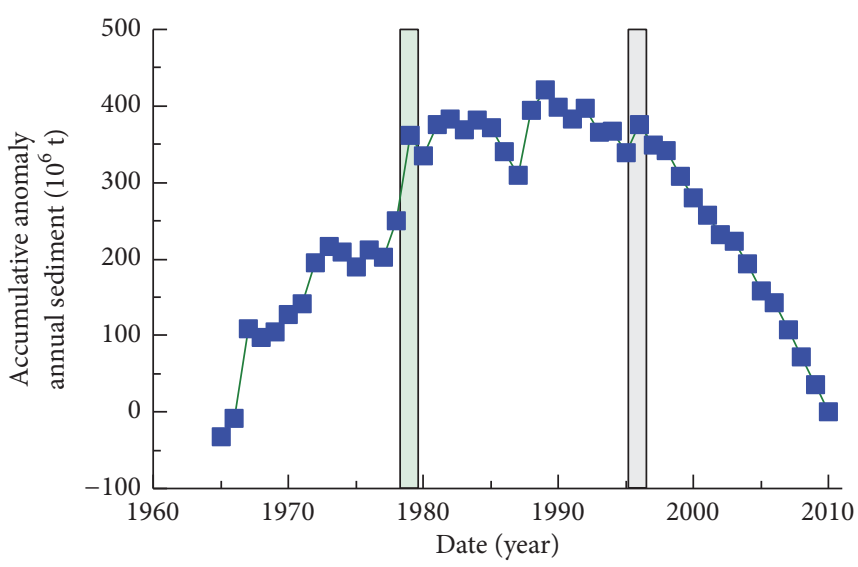

(d)

FIGURE 3: Variation in annual runoff and sediment load at Huangfu station ((a), (c) annual runoff changes and cumulative anomaly test; (b), (d) annual sediment load changes and cumulative anomaly test). 
TABLE 1: Statistics of streamflow and sediment load at the annual and flood season scales during 1965-2010.

\begin{tabular}{|c|c|c|c|c|c|c|c|}
\hline & \multirow{2}{*}{ Annual hydrological variables } & \multicolumn{3}{|c|}{ Trend test } & \multicolumn{3}{|c|}{ Change point test } \\
\hline & & $Z$ & Slope & Mean & Before 1979 & 1980-1996 & After 1997 \\
\hline \multirow{4}{*}{ Annual case } & $Q\left(10^{8} \mathrm{~m}^{3}\right)$ & -4.34 & -0.032 & 1.12 & 1.73 & 1.17 & 0.39 \\
\hline & Sed $\left(10^{4} t\right)$ & -4.28 & -109.3 & 3679.3 & 6088.7 & 3762.2 & 996.9 \\
\hline & $\mathrm{SC}\left(\mathrm{kg} / \mathrm{m}^{3}\right)$ & -2.80 & -3.76 & 279.3 & 337.5 & 276.6 & 220.2 \\
\hline & $\mathrm{Cr}(\%)$ & -5.13 & -0.3 & 9.3 & 13.8 & 9.9 & 3.7 \\
\hline \multirow{4}{*}{ Flood season } & $Q\left(10^{8} \mathrm{~m}^{3}\right)$ & -3.69 & -0.026 & 1.0 & 1.55 & 1.03 & 0.38 \\
\hline & Sed $\left(10^{4} t\right)$ & -4.24 & -108.8 & 3670.5 & 6077.6 & 3748.9 & 996.3 \\
\hline & $\mathrm{SC}\left(\mathrm{kg} / \mathrm{m}^{3}\right)$ & -3.64 & -5.09 & 318.7 & 391.2 & 328.0 & 229.6 \\
\hline & $\mathrm{Cr}(\%)$ & -4.20 & -0.2 & 9.1 & 13.2 & 9.5 & 4.3 \\
\hline
\end{tabular}

The mean annual $Q$, Sed, SC, and $\mathrm{Cr}$ within different periods were also presented in Table 1 . In general, all values of the hydrological variables showed a gentle decrease during 1980-1996 when compared to those before 1979. For example, the mean values of annual $Q$ and $\mathrm{Cr}$ decrease by $32 \%$ and $29 \%$, respectively. However, the decrease was more significant in the third period (1997-2010). All the hydrological variables reduced by more than $50 \%$ except for the SC in flood season. Particular high deceasing rates were found in average runoff and sediment load in both annual and flood season scales, which had approximately $80 \%$ decrease comparing to those during 1965-1979.

4.2. Changes of Monthly Runoff and Sediment Discharge. As mentioned above, monthly runoff and sediment load showed strong seasonal variation with extremely high proportion in the rainy season (Figure 2(a)). Monthly sediment concentration (SC) and runoff coefficient $(\mathrm{Cr})$ were plotted in Figure 2(b). The average SC during July and August was $440.5 \mathrm{~kg} / \mathrm{m}^{3}$, which is approximately three times the mean annual SC. Compared to monthly runoff, sediment load, and SC, Cr showed relatively higher values in March, suggesting effects of snowmelt on monthly runoff.

Figure 4 shows the MK trend test of the monthly $Q$, Sed, SC, and Cr within the flood season. All the monthly values displayed significant decreasing trends $(p<0.05)$ from 1965 to 2010. The MK test results (Figures 4(a) and $4(c)$ ) suggested that the decreasing of runoff and sediment load at annual and flood season scales was mainly caused by their decline in July and August. The monthly SC exhibited obvious decreasing trends from June to September. However, the runoff coefficient showed inconsistent changing trends to Q, Sed, and SC. Sens' slope of monthly Q, Sed, and SC all reduced most rapidly in July and August, while Cr decreased relatively stably during the flood season. Furthermore, the MK values of monthly $\mathrm{Cr}$ showed more significant decrease in May and October (Figure 4(d)) and relatively higher MK in August.

4.3. Variation of Daily Runoff and Sediment. According to the accumulative anomaly test, the hydrological time series were divided into three periods: 1965-1979, 1980-1996, and 19972010. We applied the flow duration curve (FDC) analysis to
TABLE 2: FDC analysis for different periods at Huangfu station.

\begin{tabular}{lcccccc}
\hline \multirow{2}{*}{ Period } & \multicolumn{3}{c}{ Flow indices $\left(\mathrm{m}^{3} / \mathrm{s}\right)$} & \multicolumn{3}{c}{ Sediment delivery $(\mathrm{kg} / \mathrm{s})$} \\
& $Q_{10}$ & $Q_{25}$ & $Q_{75}$ & $\operatorname{Sed}_{10}$ & $\operatorname{Sed}_{25}$ & $\operatorname{Sed}_{75}$ \\
\hline $1965-1979$ & 6.75 & 2.5 & 0.01 & 216 & 16.4 & 0 \\
$1980-1996$ & 4.46 & 1.45 & 0 & 92.7 & 10.9 & 0 \\
\hline $1997-2010$ & 0.74 & 0 & 0 & 2.14 & 0 & \\
\hline
\end{tabular}

the daily records within different periods for better understanding of the temporal variation of runoff and sediment discharge on daily scale [50].

We selected six indices (i.e., $Q_{10}, Q_{25}, Q_{75}, \operatorname{Sed}_{10}, \operatorname{Sed}_{25}$, and $\operatorname{Sed}_{75}$ ) to analyze temporal changes of magnitude and frequency in daily runoff and sediment delivery during three different periods. The indices of $Q_{10}, Q_{25}$, and $Q_{75}$ were, respectively, defined as the specific values with frequency of $10 \%, 25 \%$, and $75 \%$ of the daily runoff to fully represent the range of flow values. Similar indices were also examined for sediment delivery.

Figure 5 shows the FDCs for both daily runoff and sediment delivery at Huangfu station within three different periods described previously. The results suggested that there was significant decrease for both low-flow and high-flow values during 1980-2010 compared to those from 1965 to 1979. Similarly, sediment delivery illustrated evident decline in the latter two periods (1980-1996 and 1997-2010). Moreover, extreme low sediment delivery $(<0.01 \mathrm{~kg} / \mathrm{s})$ accounted for higher proportion within the period of 1997-2010. The daily sediment delivery with low values was nearly $44 \%$ within 1965-1979 but increased to $86.8 \%$ from 1997 to 2010 .

Table 2 demonstrated the daily flow and sediment delivery indices within three periods. Specifically, the low-flow values $\left(Q_{75}\right)$ were close to zero within three periods, which is the same as daily sediment delivery $\left(\operatorname{Sed}_{25}\right)$. The high-flow $\left(Q_{10}\right)$ reduced by nearly $90 \%$ within $1997-2010$ compared to that of 1965-1979. Consistently, $\operatorname{Sed}_{10}$ was $216 \mathrm{~kg} / \mathrm{s}$ during $1965-1979$ and decreased to $2.14 \mathrm{~kg} / \mathrm{s}$ in $1997-2010$.

Figure 6 shows the variations of maximum daily runoff $\left(Q_{\mathrm{md}}\right)$, sediment concentration $\left(\mathrm{SC}_{\mathrm{md}}\right)$, and sediment delivery $\left(S_{\mathrm{md}}\right)$ during $1965-2010 . Q_{\mathrm{md}}$ ranged from $1510 \mathrm{~m}^{3} / \mathrm{s}$ to $18.8 \mathrm{~m}^{3} / \mathrm{s}$ with an average of $305.8 \mathrm{~m}^{3} / \mathrm{s}$. In contrast, $\mathrm{SD}_{\mathrm{md}}$ exhibited similar variability with $Q_{\mathrm{md}}$, and a good correlation 

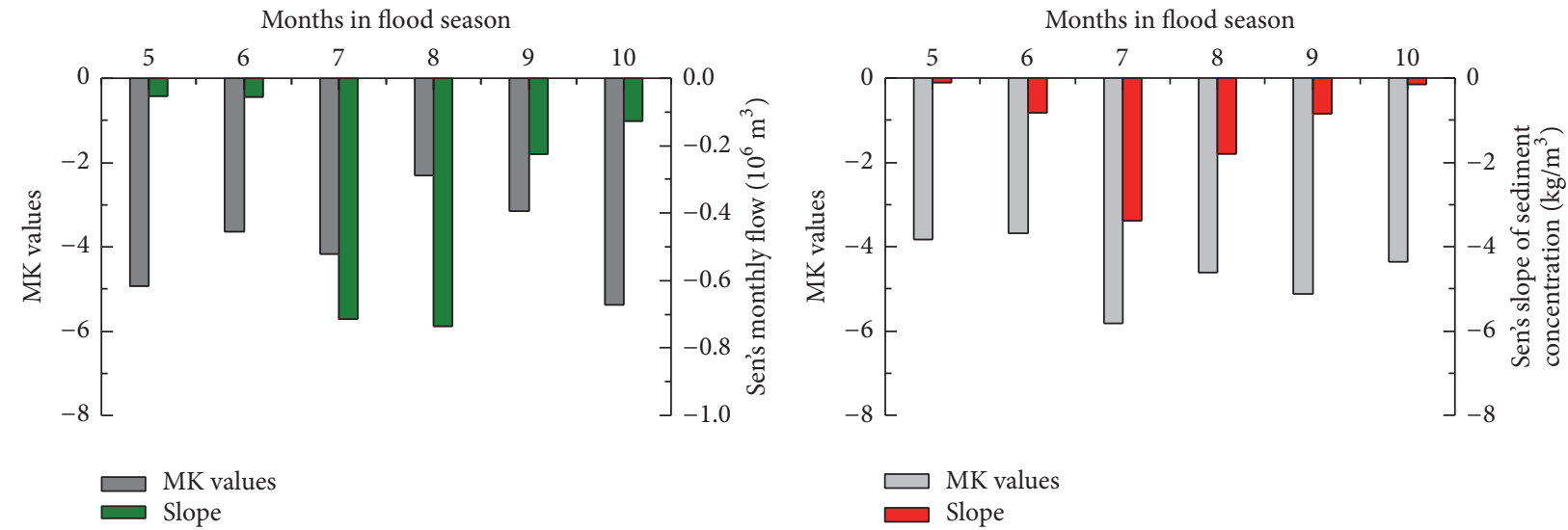

(a)

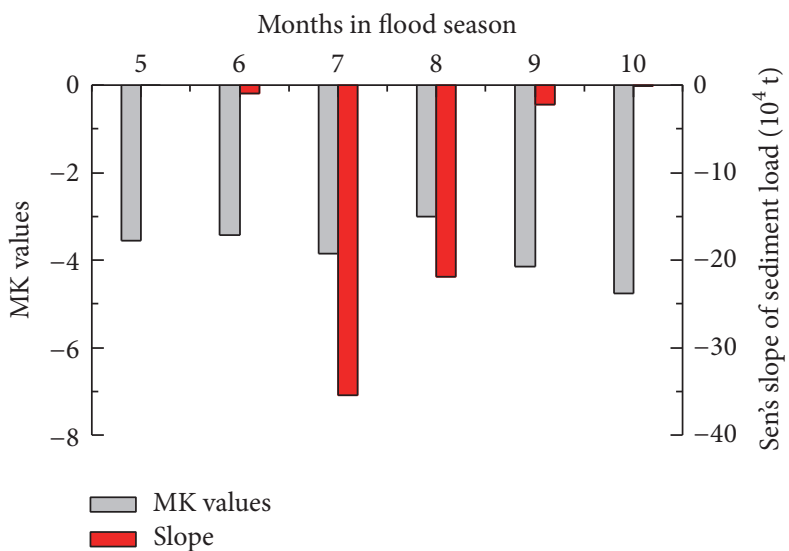

(b)

(c)

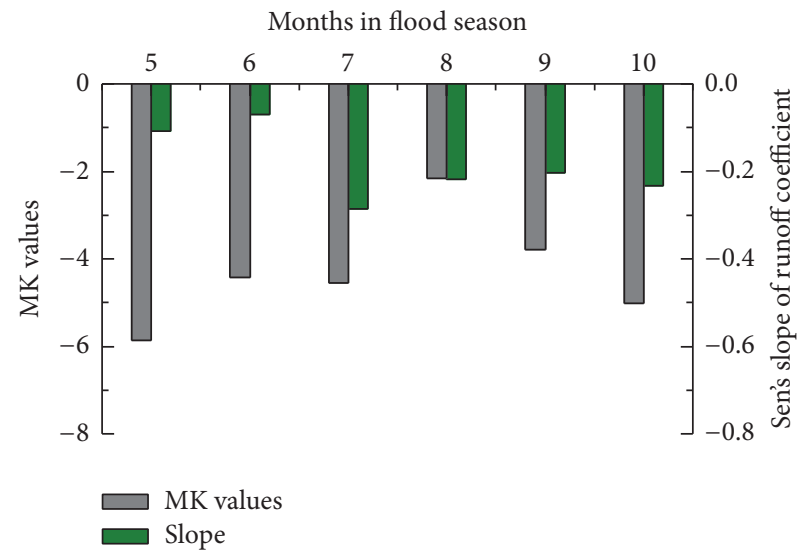

(d)

FIGURE 4: MK test of runoff and sediment indices in flood season at Huangfu station (MK test for monthly runoff (a), sediment concentration (b), sediment load (c), and runoff coefficient (d)).

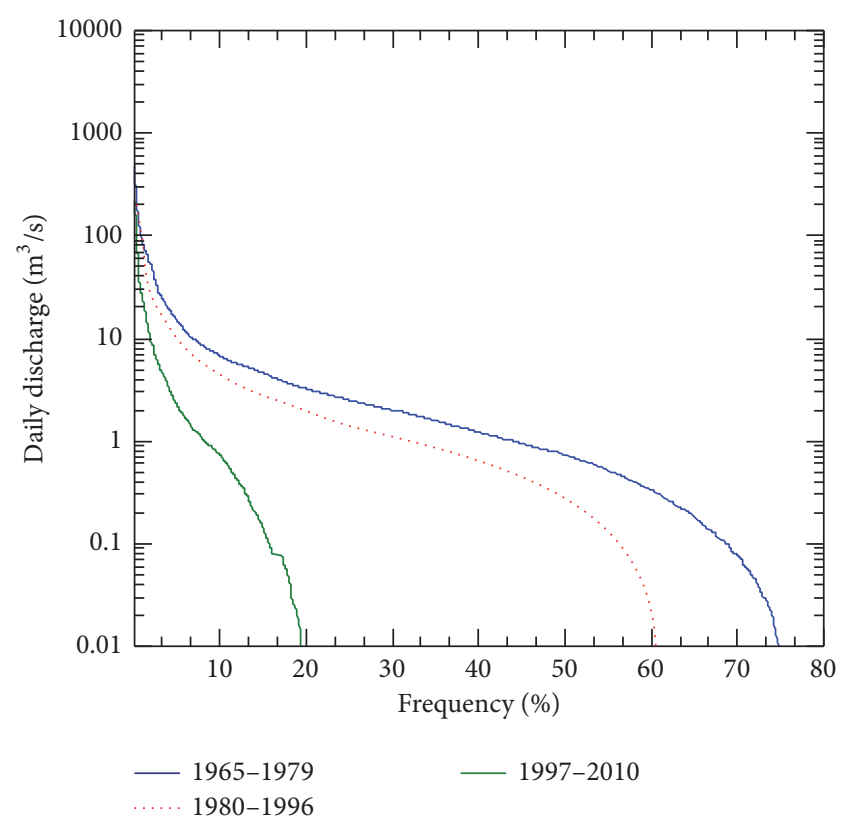

(a)

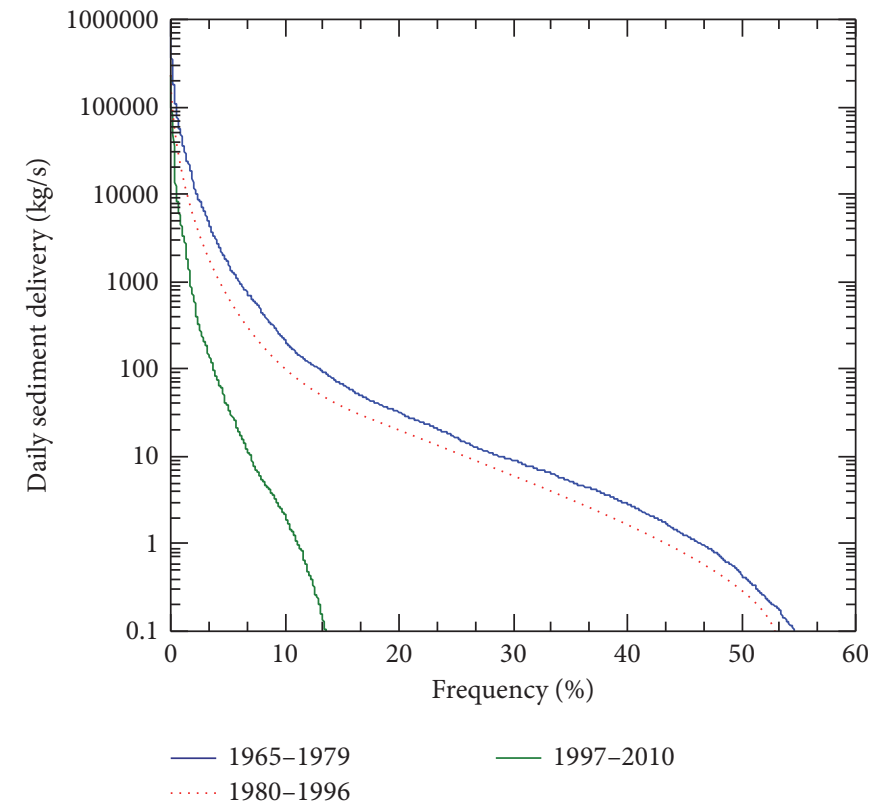

(b)

FIGURE 5: Flow duration curves of daily runoff (a) and sediment delivery (b) at Huangfu station. 


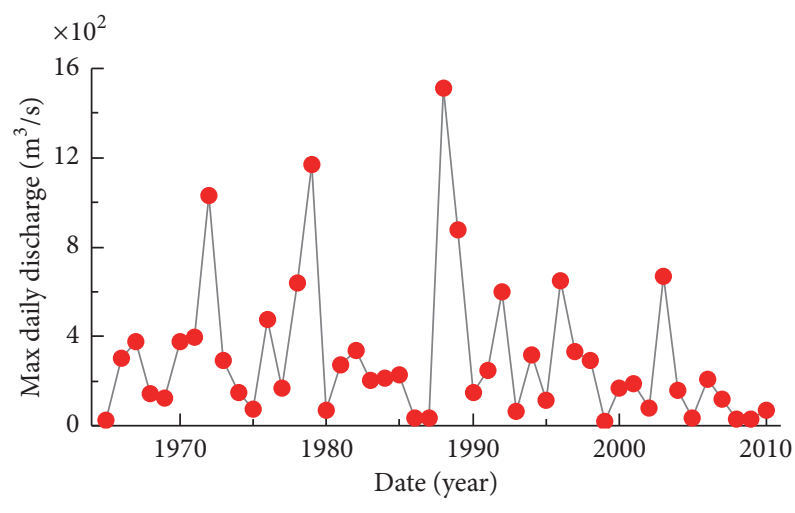

(a)

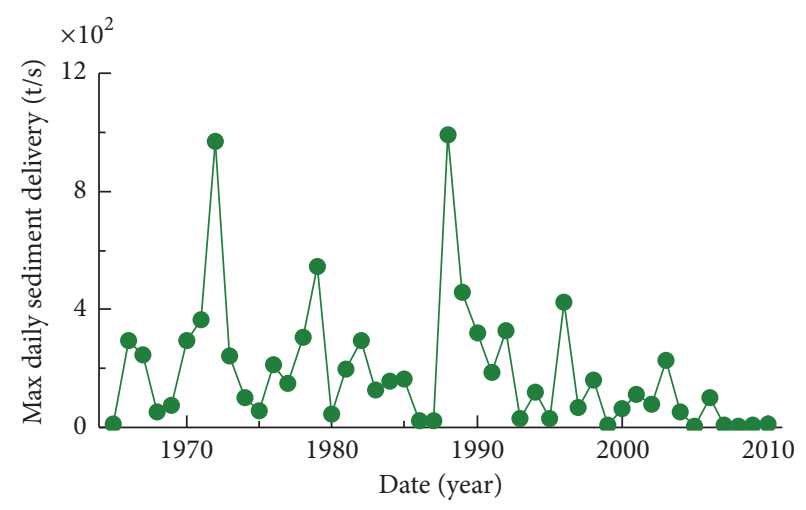

(b)

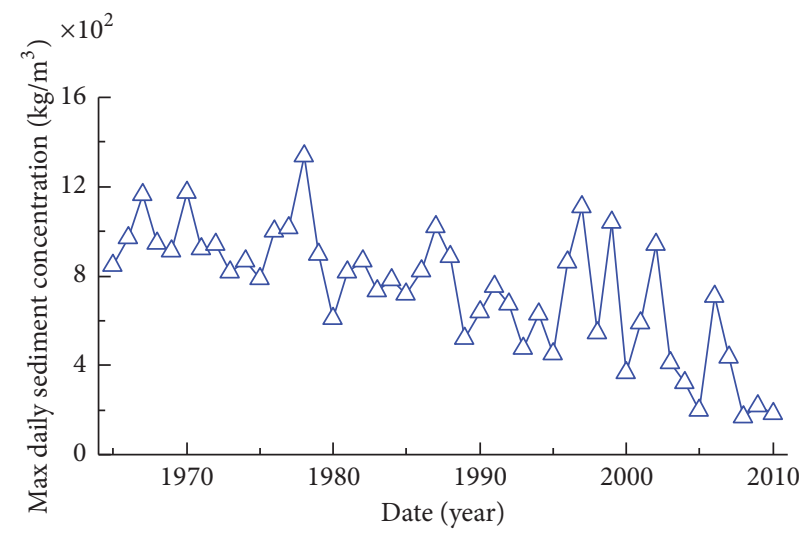

(c)

Figure 6: Maximum daily runoff (a), sediment delivery (b), and sediment concentration (c) at Huangfu station from 1965 to 2010.

coefficient $\left(R^{2}\right)$ was of 0.92 between them. Maximum $\mathrm{SD}_{\mathrm{md}}$ in 1988 was several hundred times the value in 2008. Both $Q_{m d}$ and $S_{m d}$ occurred in 1988 as a result of the intense rainstorm and flood in August of 1988. The MK test showed that $\mathrm{Sed}_{\mathrm{md}}$ and $\mathrm{SC}_{\mathrm{md}}$ had significant decreasing trends $(p<$ 0.01 ) from 1965 to 2010, while $Q_{\mathrm{md}}$ displayed insignificant changing trend.

4.4. Impacts of Climate Variability and Human Activities. Figure 7 showed the double mass curve of runoff/sediment load versus precipitation at both annual and flood season scales, along with the linear regression lines. It can be clearly seen that the changing points existed among different periods, which confirmed the results examined by the accumulative anomaly test.

As shown in Figure 7, the simple linear regression was established between the accumulative runoff-precipitation and sediment load-precipitation at both annual and flood season scales before the changing point (1965-1979), and then the impacts of climate variability and human activities were quantified based on the regression model. The relative contribution of climate change and human activities to the variations of runoff are exhibited in Table 3, and the results of sediment load changes are demonstrated in Table 4.

As shown in Table 3, the relative contribution of precipitation to annual runoff reduction was $24.4 \%$ and $25.1 \%$ during the periods of 1980-1996 and 1997-2010, respectively, whereas the human activities accounted for approximately $75.6 \%$ and $74.9 \%$. As for the flood season, the contributions of human activities to runoff reduction were $74.1 \%$ and $82.9 \%$ during the two periods, respectively.

As for sediment load (Table 4), the contributions from human activities were $56.5 \%$ during $1980-1996$ and $79.8 \%$ in 1997-2010. The results suggested that the human activities play a dominant role for both runoff and sediment load reduction in the catchment, particularly for the period of 1997-2010. For the flood season, the contribution from human activities on the reduction in sediment load was $60.6 \%$ during $1980-1996$ and $71.1 \%$ in $1997-2010$. The results suggested that the effects of human activities on annual and flood scales were not completely equal. Human activities played a more substantial role in the latter period (19972010) for both runoff and sediment load reductions in the catchment than that during 1980-1996, which implied increasing impacts of human activities.

\section{Discussion}

5.1. Attribution of Climate Changes. Precipitation directly affects the hydrological cycles in the catchment and is also considered as driving forces of soil erosion. The changes in precipitation can alter the runoff regime and sediment 


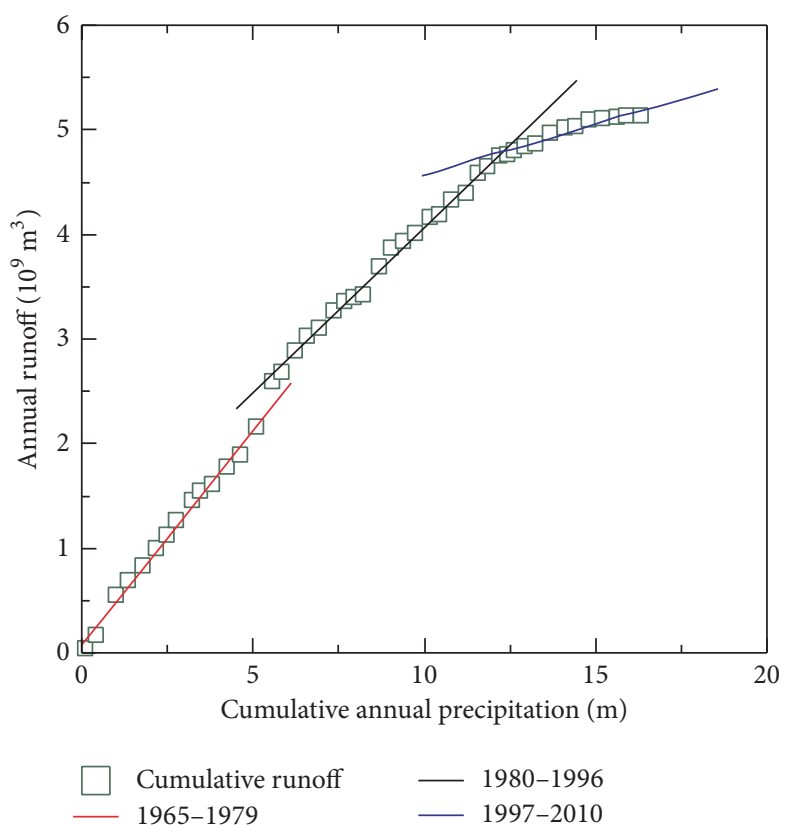

(a)

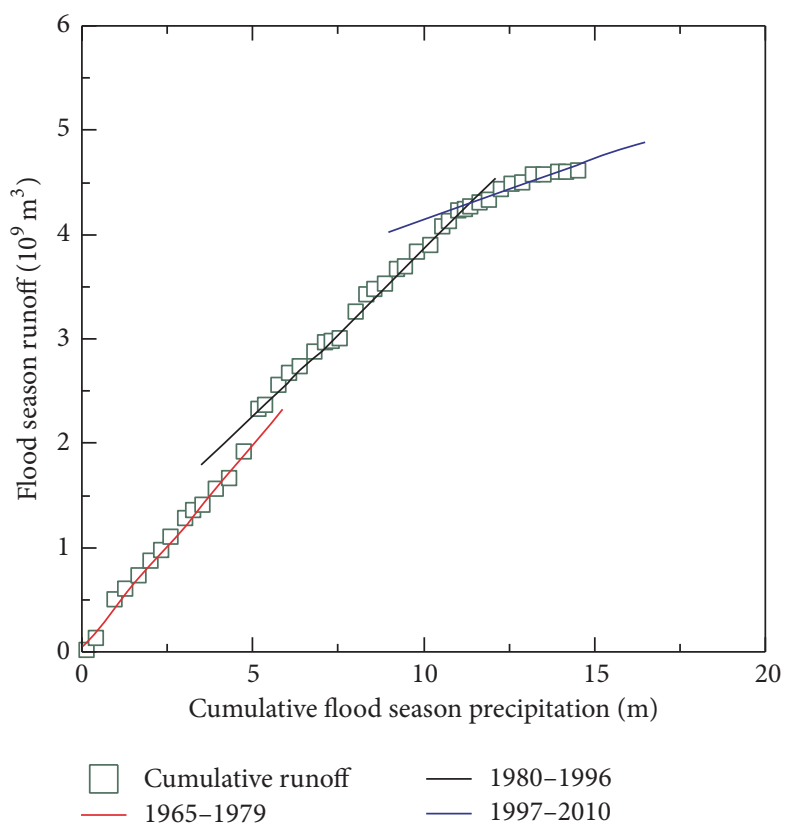

(c)

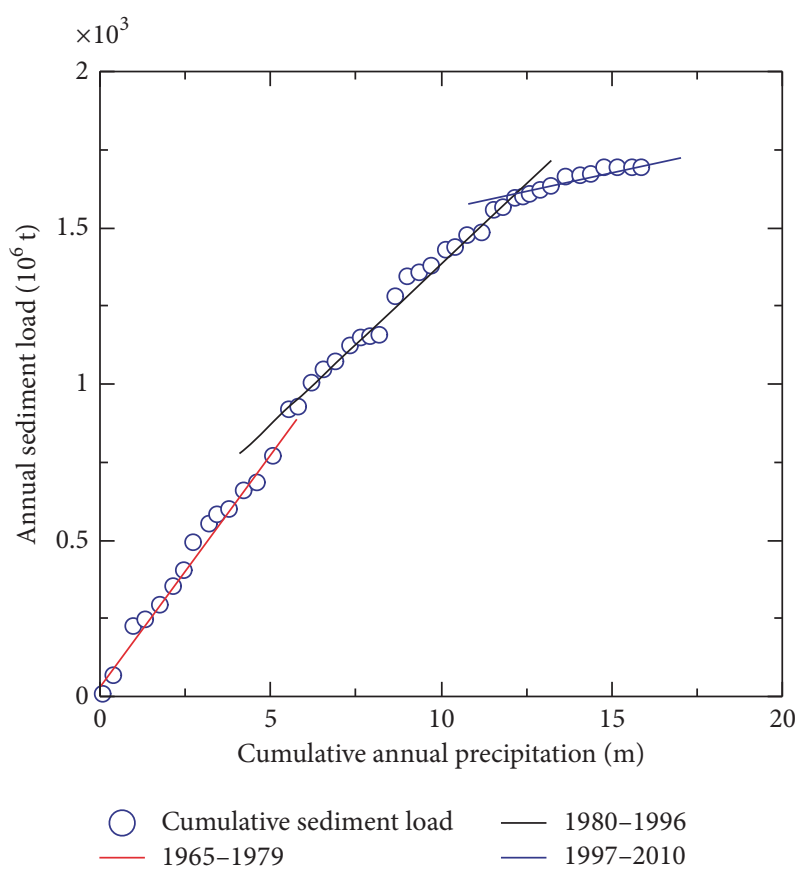

(b)

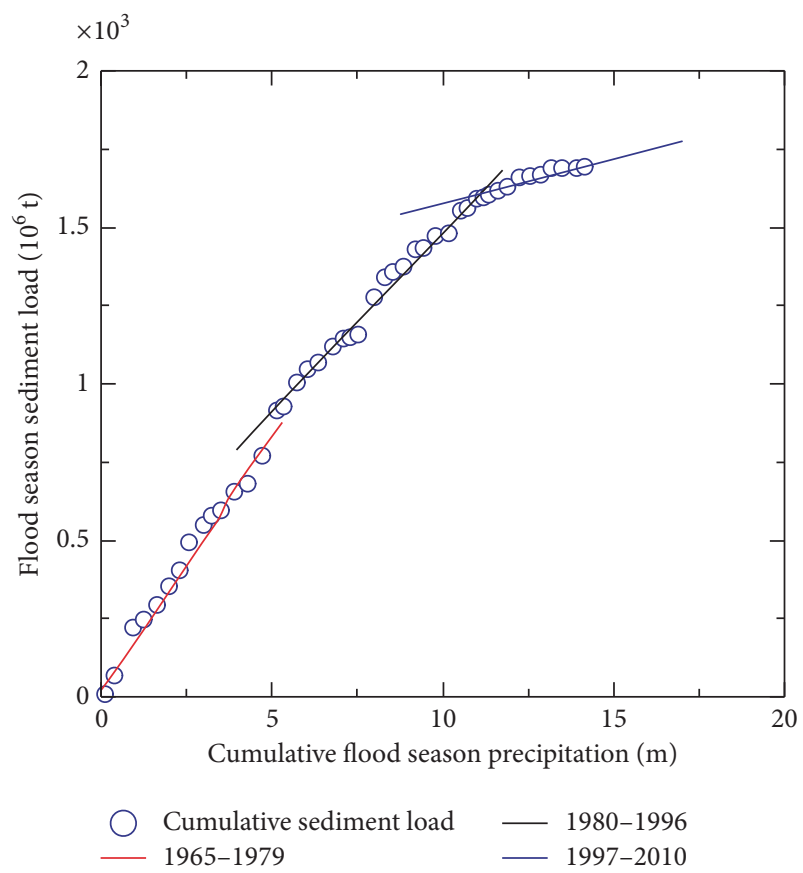

(d)

FIGURE 7: Double mass curve analysis of runoff-precipitation $(a, c)$ and sediment load-precipitation (b, d) at annual and flood season scale.

transport capacity in the watershed [51]. As Zhao et al. [33] reported, the Loess Plateau experienced a relative warm and dry period during the past several decades. The increasing temperature may cause upward trend of potential evapotranspiration, which influences the regional water balance. As shown in Figure 8, the annual precipitation showed an insignificant decrease in the catchment from 1965 to 2010, and annual temperature exhibited an upward trend.

When compared to the changes of precipitation and temperature, runoff and sediment load illustrated more remarkable decrease in the study period. Annual runoff and sediment load declined by approximately $77.2 \%$ and 
TABLE 3: Impacts of precipitation $(P)$ and human activities (HA) on changes of runoff $\left(10^{9} \mathrm{~m}^{3}\right)$.

\begin{tabular}{|c|c|c|c|c|c|}
\hline & Period & Observed runoff & Estimated runoff & Impact of $P$ & Impact of HA \\
\hline \multirow{3}{*}{ Annual scale } & 1955-1979 & 0.173 & & & \\
\hline & 1980-1996 & 0.117 & 0.131 & $0.014(24.4 \%)$ & $0.042(75.6 \%)$ \\
\hline & $1980-2010$ & 0.039 & 0.139 & $0.033(25.1 \%)$ & $0.1(74.9 \%)$ \\
\hline \multirow{3}{*}{ Flood season } & 1955-1979 & 0.127 & & & \\
\hline & 1980-1996 & 0.103 & 0.109 & $0.006(25.9 \%)$ & $0.0018(74.1 \%)$ \\
\hline & 1980-2010 & 0.038 & 0.112 & $0.015(17.1 \%)$ & $0.074(82.9 \%)$ \\
\hline
\end{tabular}

TABLE 4: Impacts of precipitation $(P)$ and human activities (HA) on changes of sediment load $\left(10^{6} \mathrm{t}\right)$.

\begin{tabular}{|c|c|c|c|c|c|}
\hline & Period & Sediment load & & Impact of $P$ & Impact of HA \\
\hline \multirow{3}{*}{ Annual scale } & $1955-1979$ & 60.86 & & & \\
\hline & 1980-1996 & 37.66 & 49.30 & $10.09(43.5 \%)$ & $13.11(56.5 \%)$ \\
\hline & $1980-2010$ & 10.50 & 50.67 & $10.19(20.2 \%)$ & $40.17(79.8 \%)$ \\
\hline \multirow{3}{*}{ Flood season } & 1955-1979 & 60.77 & & & \\
\hline & 1980-1996 & 37.49 & 47.70 & 9.17 (39.4\%) & $14.10(60.6 \%)$ \\
\hline & $1980-2010$ & 9.96 & 46.10 & $14.67(28.8 \%)$ & $36.14(71.1 \%)$ \\
\hline
\end{tabular}

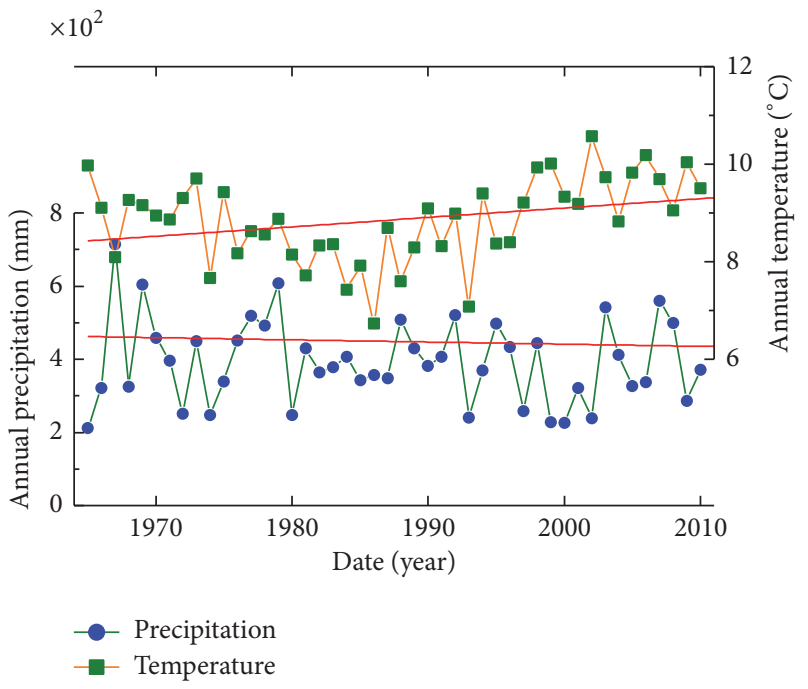

FIGURE 8: Trends in annual precipitation and temperature in the Huangfuchuan catchment.

83.4\% after 1997 comparing to those between 1965 and 1979, respectively. However, annual precipitation showed relatively gentile variation during the past five decades. Furthermore, neither precipitation nor temperature showed abrupt changing points that were detected in runoff and sediment load.

Figure 9 shows the relationship of runoff-precipitation and sediment load-precipitation at both annual and flood season scales. It can be clearly seen that the correlations of runoff-precipitation and sediment load-precipitation were much better before the transition year. Particularly for the period of 1997-2010, the correlations between the two variables were much worse, which implied that intense human activities greatly altered the hydrological processes. In addition, the linear regression lines after the breakpoints were situated below the lines of the reference period. This indicated that the same precipitation yielded less runoff and sediment load within the changing period than those in the reference period.

The aforementioned analysis implies that intensive human activities played the dominant role for runoff and sediment load reduction. Zhao et al. [33] addressed that climate variability contributed $16.6 \%$ to the reduction of runoff and the remaining $83.4 \%$ was attributed to the various human activities in the Huangfuchuan catchment. The differences between the results are mainly due to the assumptions of different methods and the data periods that were used for investigation. For example, Zhou addressed that variability in precipitation contributed $47.2 \%$ during 1977-1999 and $11.3 \%$ within 2000-2007 to the sediment reduction in the Tuwei catchment. In addition, distinct contribution from climate variability and human activities existed among different catchments on the Loess Plateau [34]. In a loess catchment, Gao et al. [32] found that human activities contributed more than climate changes to the decrease in runoff $(67.13 \%$ versus $32.87 \%)$ and sediment load (80.10\% versus $19.90 \%)$. This may infer that lithology, geomorphology, and climate patterns in the catchment play important role in soil erosion and sediment yield [52]. The Huangfuchuan catchment had relative less precipitation than those in the southern Loess Plateau and was covered by sparse vegetation with a large area of sandy area and badland [53].

5.2. Attribution of Human Activities. The above analysis suggested that intense human activities are the dominant factors leading to noticeable reduction in both runoff and sediment at different scales. Since the 1950s, majority of soil and water conservation measures had been implemented on the Chinese Loess Plateau. As shown in Figure 10, the percentage of area covered/controlled by soil and water 


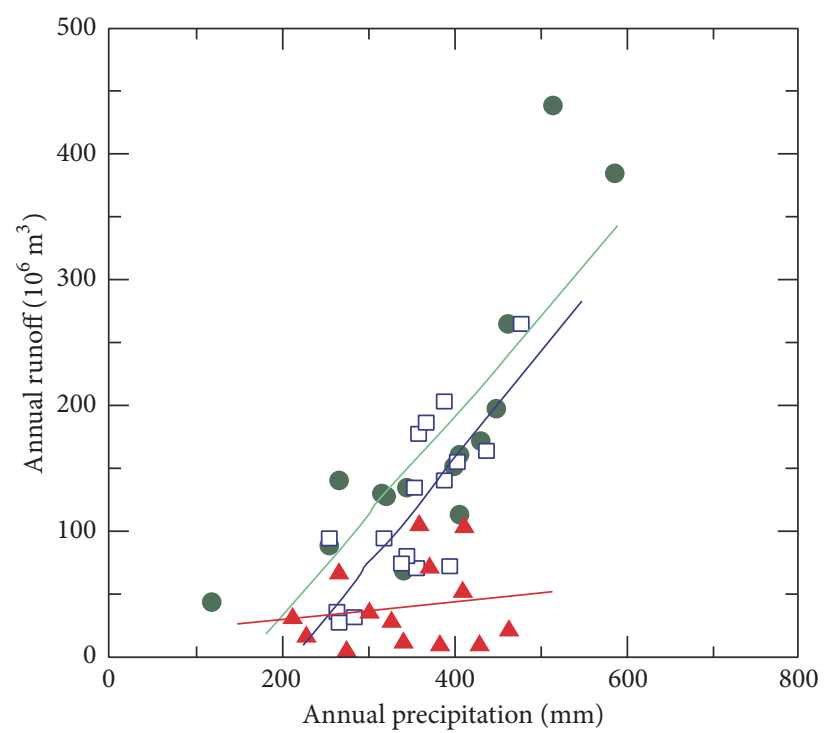

- 1965-1979

- 1997-2010

1980-1996

(a)

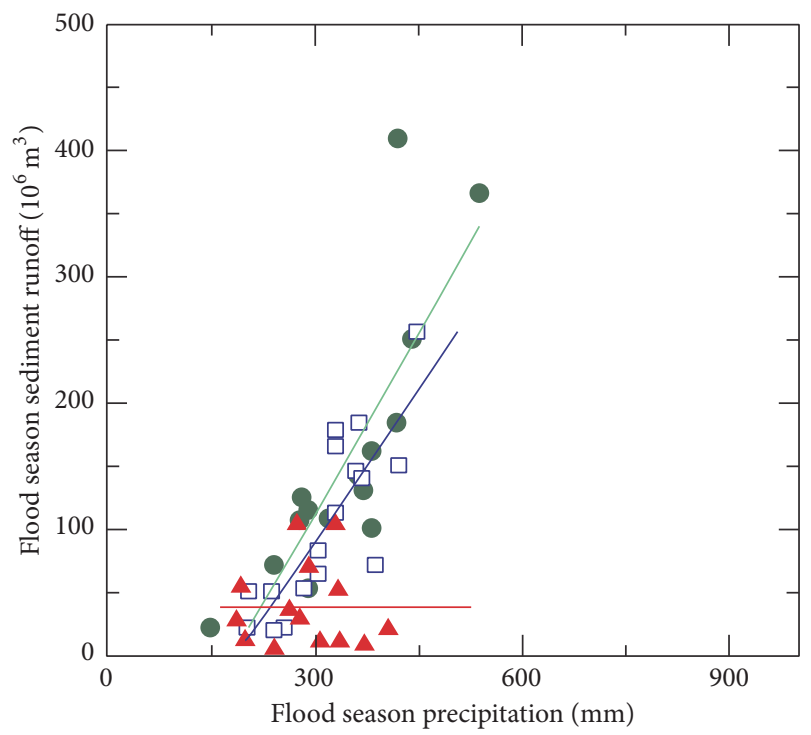

- 1965-1979

A 1997-2010

ㅁ 1980-1996

(c)

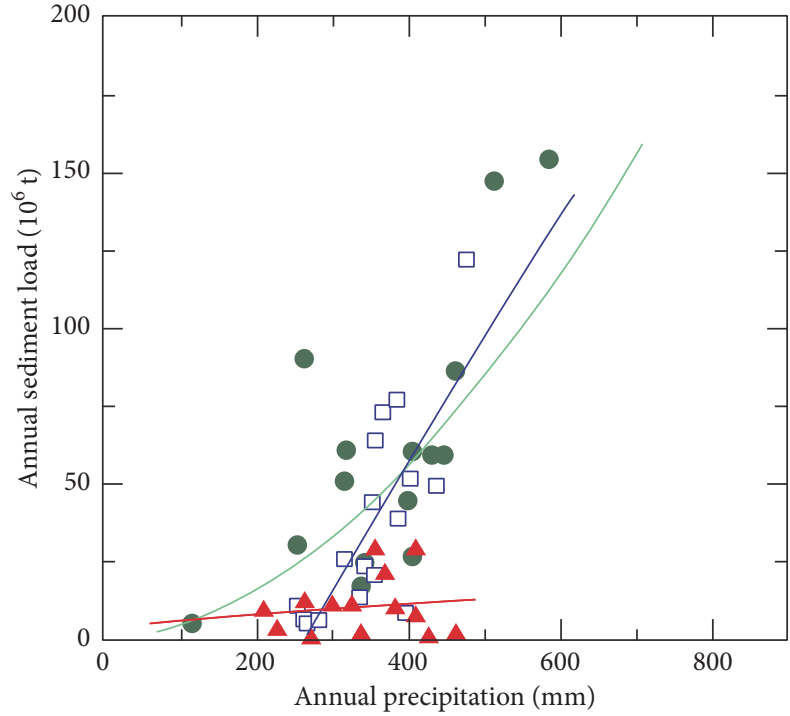

- 1965-1979

- 1997-2010

$\square$ 1980-1996

(b)

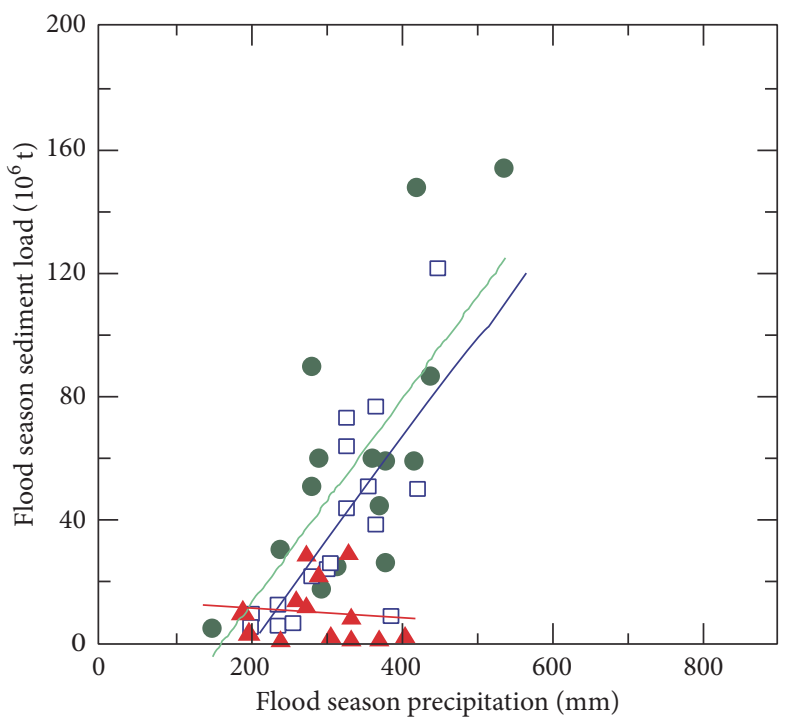

1965-1979

1997-2010

口 1980-1996

(d)

FIGURE 9: Correlation between annual and flood season runoff, sediment load, and precipitation in the catchment from 1965 to 2010 ((a), (b) relationship of annual runoff and sediment versus precipitation; (c), (d) relationship of flood season runoff and sediment load versus precipitation).

conservation measures increased from $42.9 \mathrm{~km}^{2}(1.3 \%)$ in 1959 to $1765 \mathrm{~km}^{2}(54.4 \%)$ in 2006 . In detail, the soil and water conservation measures did not show obvious increase until the late of 1970s, suggesting limited effects on changes in runoff and sediment load. This can explain the good relationship between runoff/sediment and precipitation. The measures increased very rapidly since a large number of conservation projects were launched afterwards. The abrupt changes in both runoff and sediment load were consistent with the implementation of "Grain for Green" project, which was the largest ecological restoration project throughout the world [30]. It promoted the conversion slope arable land to forest or grassland to control the severe soil erosion on the Loess Plateau.

As displayed in Figure 10, the soil and water conservation measures consisted of both biological and engineering 


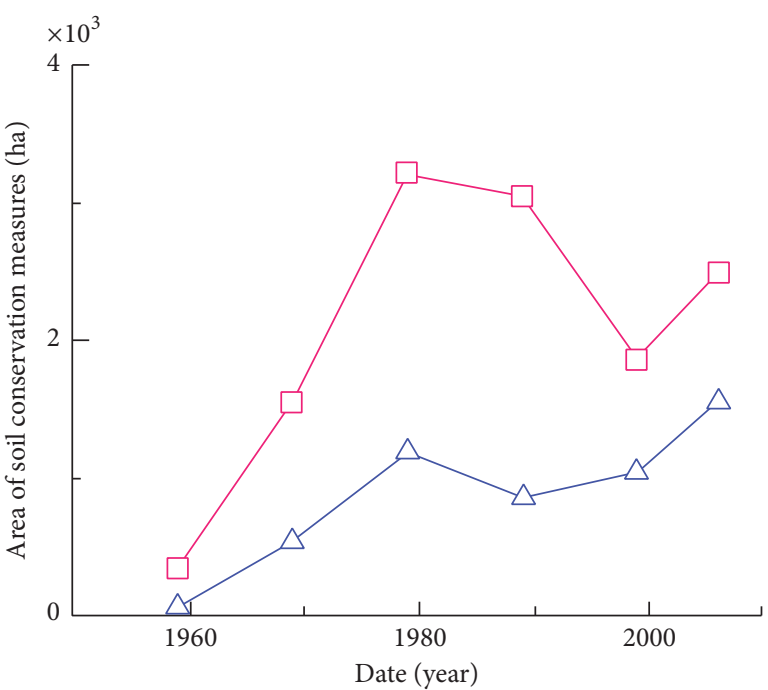

$-\checkmark$ Check dams $-\square$ Terrace

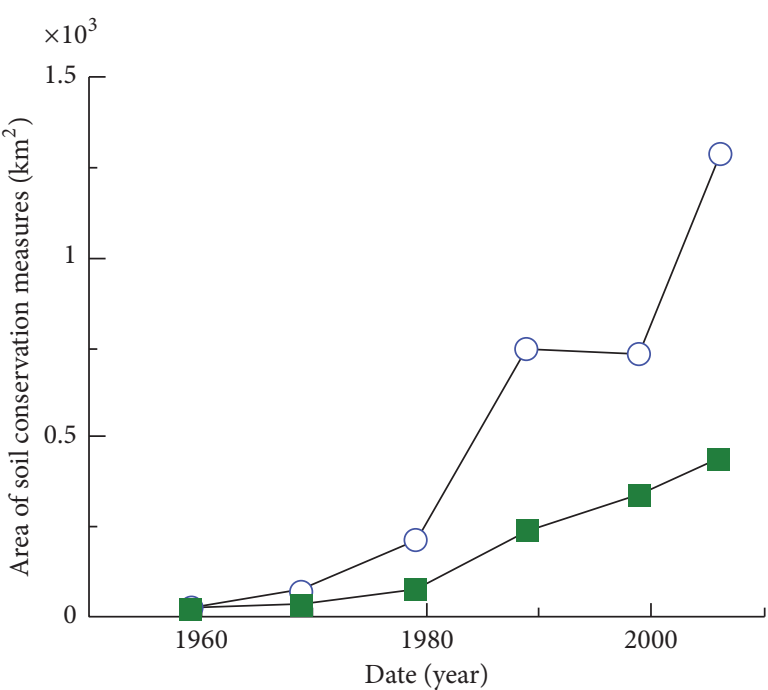

- Forest

Grassland

(a)

(b)

FIGURE 10: Statistics of soil and water conservation in the upstream Huangfu station.

measures. The biological measures such as afforestation and grassing increased from $111.62 \mathrm{~km}^{2}$ at the end of $1960 \mathrm{~s}$ and reached $1724.6 \mathrm{~km}^{2}$ in 2006 , accounting for more than $50 \%$ of the catchment. These measures can increase the rainfall interception and lead to more water infiltrated into the soil, thus reducing the surface runoff and sediment transport capacity. Furthermore, the runoff peaks are reduced and delayed due to vegetation restoration. Zhao et al. [33] addressed that biological measures may have delayed effects on runoff because the plants take up water and accelerate its evapotranspiration. McVicar et al. [28] found that the afforestation would reduce the annual runoff from $10 \%$ to $70 \%$ in the Loess Plateau regions.

The engineering measures, mainly consisting of terracing and check dams construction, can trap large amount of water and sediment upstream. These techniques have immediate and substantial effects on runoff and sediment transport. $\mathrm{Xu}$ et al. [54] reported that check dam has been the most effective measure to trap sediment. Ran et al. [55] analyzed sediment trapping by check dams in the Huangfuchuan catchment for the period of 1954 to 1996, and a reduction in sediment load of up to $60 \%$ can be attributed to check dams. An investigation from Boix-Fayos et al. [56] found that the check dams can reduce the sediment yield up to $77 \%$ in the Rogativa catchment in Spain. According to Tian et al. [39], check dams have become the main soil and water conservation measures in the Huangfuchuan catchment, with more than $70 \%$ of the area controlled by check dams by 2010. Shi et al. [57] applied the Digital Yellow River Integrated Model to simulate the check dams' effects on runoff and found approximately $39 \%$ of interception effects of sediment trapping dams on decline of runoff.
In this study, the double mass cure method was used to investigate the effects of climate variability and human activities on runoff and sediment load changes. This method, although easily applied, was similar to other regression models utilizing the relationship between runoff/sediment load and precipitation, while the results may largely be influenced by the correlations (which determined the model application in the changing periods) between the variables [19]. Another kind of method estimated the effects of soil and water conservation measures according to the trapping efficiencies of different measures on runoff and sediment transport. For example, Ran et al. [55] calculated different contributions to sediment load reduction of each kind of measures based on their quantities. However, the abovementioned methods ignored the changes in hydrological processes and sediment transportation and were mostly empirical-based. Further studies should be undertaken by using physically based model, which considers the driving mechanism of runoff and sediment yield and transportation.

5.3. Perspective for Watershed Management. In the study area, a significant decrease in runoff has been detected. With rapidly growing economy and increasing water demand, the policy makers faced the new changes for decreasing water supplies in this region $[58,59]$. A series of engineering and biological practices have been implemented to control severe soil erosion and floods, restore the ecosystem, and regulate the river system for agricultural production. However, due to the high intensity of storms and soil erodibility, a comprehensive set of reasonable soil and water conservation practices in the Huangfuchuan catchment are recommended. Due to limited precipitation and less fertile loess soil, the relative dry 
climate condition is the main limiting factor for tree/grass growth. Thus, long-term sustainable conservation measures are possibly made by increasing afforestation survival rates through protecting the native species, conserving species richness, and insisting on natural rehabilitation [60, 61].

Check dam has become the dominant soil and water conservation measure in the study area, which trapped large amount of sediment [12]. Recent study by Zhao et al. [43] suggested that check dam can contribute approximately more than $50 \%$ of reduction to the total sediment load in the Huangfuchuan catchment. It has to be noted that the check dams are short-term measures for retaining the inflow sediment. Frequently occurring floods not only transport large amount of sediment into the check dams, but can destroy the dams and released large volumes of runoff and sediment, which threaten the security of downstream cities and people. Thus, it is greatly necessary to reduce the sediment transport capacity from the hillslopes by increasing vegetation cover, and a combination of vegetation restoration and engineering measures is strongly encouraged for soil erosion control.

\section{Conclusions}

This study investigated the variation of runoff and sediment load at different temporal scales at Huangfuchuan catchment from 1965 to 2010. Impacts of climate variability and human activities were quantified using a simple linear regression method, and potential causes for the variation of runoff and sediment load were identified. The conclusion of our study can be summarized as follows.

The annual runoff and sediment load displayed significant decreasing trend $(p<0.01)$ with reduction rates of $-3.2 \times 10^{6} \mathrm{~m}^{3} / \mathrm{a}$ and $-1.09 \mathrm{Mt} / \mathrm{a}$, respectively. The cumulative anomaly suggested two breakpoints occurring in 1979 and 1996; thereby three phases were divided as 1965-1979, 19801996, and 1997-2010. The FDCs for daily runoff and sediment delivery implied decreases in both low-flow and flood peaks. All the monthly and daily flow and sediment load indices displayed marked decrease in the latter two periods.

The reduced precipitation contributed approximately a quarter to the annual runoff decrease during the periods of 1980-1996 and 1997-2010. For sediment load, it was 43.5\% within 1980-1996 and 20.2\% during 1997-2010, while the effects of human activities on annual and flood scales were not completely equal, particularly during the period of 19801996. Furthermore, we found an increased effect of soil and water conservation measures in recent years on the variation of runoff and sediment load in the Huangfuchuan catchment.

\section{Competing Interests}

The authors declare no conflict of financial interests.

\section{Acknowledgments}

The work was supported by National Natural Sciences Foundation of China (Grant nos. 51509206, 41671279), the National Key Scientific Research Project (2016YFC0402401), the Fundamental Research Funds for the Central Universities (2014YB066), and the Special-Funds of Scientific Research Programs of State Key Laboratory of Soil Erosion and Dryland Farming on the Loess Plateau (A314021403-Q2). The authors would like to express their great appreciation to the Hydrology Bureau of the Yellow River Water Resources Commission for providing valuable climatic and hydrological data.

\section{References}

[1] J. D. Carriquiry and A. Sánchez, "Sedimentation in the Colorado River delta and Upper Gulf of California after nearly a century of discharge loss," Marine Geology, vol. 158, no. 1-4, pp. 125-145, 1999.

[2] J. P. M. Syvitski, C. J. Vörösmarty, A. J. Kettner, and P. Green, "Impact of humans on the flux of terrestrial sediment to the global coastal ocean," Science, vol. 308, no. 5720, pp. 376-380, 2005.

[3] D. E. Walling, "Human impact on land-ocean sediment transfer by the world's rivers," Geomorphology, vol. 79, no. 3-4, pp. 192216, 2006.

[4] H. J. Wang, Y. Saito, Y. Zhang, N. S. Bi, X. X. Sun, and Z. S. Yang, "Recent changes of sediment flux to the western Pacific Ocean from major rivers in East and Southeast Asia," Earth-Science Reviews, vol. 108, no. 1-2, pp. 80-100, 2011.

[5] P. Borrelli, M. Märker, and B. Schütt, "Modelling post-treeharvesting soil erosion and sediment deposition potential in the turano river basin (Italian central apennine)," Land Degradation and Development, vol. 26, no. 4, pp. 356-366, 2015.

[6] S. Cohen, A. J. Kettner, and J. P. M. Syvitski, "Global suspended sediment and water discharge dynamics between 1960 and 2010: continental trends and intra-basin sensitivity," Global and Planetary Change, vol. 115, pp. 44-58, 2014.

[7] P. C. D. Milly, K. A. Dunne, and A. V. Vecchia, "Global pattern of trends in streamflow and water availability in a changing climate," Nature, vol. 438, no. 7066, pp. 347-350, 2005.

[8] L. Fleskens and L. C. Stringer, "Land management and policy responses to mitigate desertification and land degradation," Land Degradation and Development, vol. 25, no. 1, pp. 1-4, 2014.

[9] C. J. Vörösmarty, P. Green, J. Salisbury, and R. B. Lammers, "Global water resources: vulnerability from climate change and population growth," Science, vol. 289, no. 5477, pp. 284-288, 2000.

[10] B. Q. Zhang, P. T. Wu, X. N. Zhao, Y. B. Wang, X. D. Gao, and X. C. Cao, "A drought hazard assessment index based on the VICPDSI model and its application on the Loess Plateau, China," Theoretical and Applied Climatology, vol. 114, no. 1-2, pp. 125$138,2013$.

[11] Z. Lu, S. Zou, Z. Qin et al., "Hydrologic responses to land use change in the loess plateau: case study in the upper fenhe river watershed," Advances in Meteorology, vol. 2015, Article ID 676030, 10 pages, 2015.

[12] D.-C. Ran, Q.-H. Luo, Z.-H. Zhou, G.-Q. Wang, and X.-H. Zhang, "Sediment retention by check dams in the HekouzhenLongmen Section of the Yellow River," International Journal of Sediment Research, vol. 23, no. 2, pp. 159-166, 2008.

[13] G. Q. Wang, J. Y. Zhang, J. L. Jin et al., "Assessing water resources in China using PRECIS projections and a VIC model," Hydrology and Earth System Sciences, vol. 16, no. 1, pp. 231-240, 2012. 
[14] Y. Wang, Y. Ding, B. Ye, F. Liu, J. Wang, and J. Wang, "Contributions of climate and human activities to changes in runoff of the Yellow and Yangtze rivers from 1950 to 2008," Science China Earth Sciences, vol. 56, no. 8, pp. 1398-1412, 2013.

[15] D. E. Walling and D. Fang, "Recent trends in the suspended sediment loads of the world's rivers," Global and Planetary Change, vol. 39, no. 1-2, pp. 111-126, 2003.

[16] C. Liu, J. Sui, and Z.-Y. Wang, "Sediment load reduction in Chinese rivers," International Journal of Sediment Research, vol. 23, no. 1, pp. 44-55, 2008.

[17] Q. Zhang, C.-Y. Xu, and T. Yang, "Variability of water resource in the Yellow River basin of past 50 years, China," Water Resources Management, vol. 23, no. 6, pp. 1157-1170, 2009.

[18] M. Mekonnen, S. D. Keesstra, L. Stroosnijder, J. E. M. Baartman, and J. Maroulis, "Soil conservation through sediment trapping: a review," Land Degradation \& Development, vol. 26, no. 6, pp. 544-556, 2015.

[19] X. Mu, X. Zhang, H. Shao et al., "Dynamic changes of sediment discharge and the influencing factors in the yellow river, China, for the recent 90 years," Clean-Soil, Air, Water, vol. 40, no. 3, pp. 303-309, 2012.

[20] Y. Sato, X. Ma, J. Xu et al., "Analysis of long-term water balance in the source area of the Yellow River basin," Hydrological Processes, vol. 22, no. 11, pp. 1618-1629, 2008.

[21] F. Wang, G. J. Zhao, X. M. Mu, P. Gao, and W. Y. Sun, "Regime shift identification of runoff and sediment loads in the Yellow River Basin, China," Water, vol. 6, no. 10, pp. 3012-3032, 2014.

[22] W. Y. Yao, J. H. Xu, and D. C. Ran, Assessment of Changing Trends in Streamflow and Sediment Fluxes in the Yellow River Basin, Yellow River Conservancy Press, Zhengzhou, China, 2011 (Chinese).

[23] J. A. Warrick and D. M. Rubin, "Suspended-sediment rating curve response to urbanization and wildfire, Santa Ana River, California," Journal of Geophysical Research: Earth Surface, vol. 112, no. 2, Article ID F02018, 2007.

[24] H. Komatsu, Y. Shinohara, T. Kume, and K. Otsuki, "Changes in peak flow with decreased forestry practices: analysis using watershed runoff data," Journal of Environmental Management, vol. 92, no. 6, pp. 1528-1536, 2011.

[25] S. Cao, "Impact of China's large-scale ecological restoration program on the environment and society in arid and semiarid areas of China: achievements, problems, synthesis, and applications," Critical Reviews in Environmental Science and Technology, vol. 41, no. 4, pp. 317-335, 2011.

[26] Q. Feng, H. Ma, X. M. Jiang, X. Wang, and S. X. Cao, "Who and what caused desertification in China," Scientific Reports, vol. 5, Article ID 15998, 2015.

[27] J. Y. Jiao, Z. J. Wang, G. J. Zhao, W. Z. Wang, and X. M. Mu, "Changes in sediment discharge in a sediment-rich region of the Yellow River from 1955 to 2010: implications for further soil erosion control," Journal of Arid Land, vol. 6, no. 5, pp. 540-549, 2014.

[28] T. R. McVicar, L. Li, T. G. Van Niel et al., "Developing a decision support tool for China's re-vegetation program: simulating regional impacts of afforestation on average annual streamflow in the Loess Plateau," Forest Ecology and Management, vol. 251, no. 1-2, pp. 65-81, 2007.

[29] C. Miao, J. Ni, A. G. L. Borthwick, and L. Yang, "A preliminary estimate of human and natural contributions to the changes in water discharge and sediment load in the Yellow River," Global and Planetary Change, vol. 76, no. 3-4, pp. 196-205, 2011.
[30] X. Yue, X. Mu, G. Zhao, H. Shao, and P. Gao, "Dynamic changes of sediment load in the middle reaches of the Yellow River basin, China and implications for eco-restoration," Ecological Engineering, vol. 73, pp. 64-72, 2014.

[31] L. Chen and S. X. Cao, "Lack of integrated solutions hinders environmental recovery in China," Ecological Engineering, vol. 54, pp. 233-235, 2013.

[32] G. Y. Gao, Y. Ma, and B. J. Fu, "Multi-temporal scale changes of streamflow and sediment load in a loess hilly watershed of China," Hydrological Processes, vol. 30, no. 3, pp. 365-382, 2016.

[33] G. Zhao, P. Tian, X. Mu, J. Jiao, F. Wang, and P. Gao, "Quantifying the impact of climate variability and human activities on streamflow in the middle reaches of the Yellow River basin, China," Journal of Hydrology, vol. 519, pp. 387-398, 2014.

[34] G. Q. Wang, J. Y. Zhang, J. L. Jin et al., "Regional calibration of a water balance model for estimating stream flow in ungauged areas of the Yellow River Basin," Quaternary International, vol. 336, pp. 65-72, 2014.

[35] S. Wang, B. J. Fu, S. L. Piao et al., "Reduced sediment transport in the Yellow River due to anthropogenic changes," Nature Geoscience, vol. 9, no. 1, pp. 38-41, 2016.

[36] K. Xu, J. D. Milliman, and H. Xu, “Temporal trend of precipitation and runoff in major Chinese Rivers since 1951," Global and Planetary Change, vol. 73, no. 3-4, pp. 219-232, 2010.

[37] S. Wang, M. Yan, Y. Yan, C. Shi, and L. He, "Contributions of climate change and human activities to the changes in runoff increment in different sections of the Yellow River," Quaternary International, vol. 282, pp. 66-77, 2012.

[38] P. Rustomji, X. P. Zhang, P. B. Hairsine, L. Zhang, and J. Zhao, "River sediment load and concentration responses to changes in hydrology and catchment management in the Loess Plateau region of China," Water Resources Research, vol. 44, no. 7, 2008.

[39] P. Tian, G. J. Zhao, X. M. Mu, F. Wang, P. Gao, and Z. J. Mi, "Check dam identification using multisource data and their effects on streamflow and sediment load in a Chinese Loess Plateau catchment," Journal of Applied Remote Sensing, vol. 7, no. 1, Article ID 13092, 2013.

[40] E. Li, X. Mu, G. Zhao, and P. Gao, "Multifractal detrended fluctuation analysis of streamflow in the yellow river basin, China," Water, vol. 7, no. 4, pp. 1670-1686, 2015.

[41] J. Sui, Y. He, and B. W. Karney, "Flow and high sediment yield from the Huangfuchuan watershed," International Journal of Environmental Science and Technology, vol. 5, no. 2, pp. 149-160, 2008.

[42] G. J. Zhao, A. Klik, X. M. Mu, F. Wang, P. Gao, and W. Y. Sun, "Sediment yield estimation in a small watershed on the northern Loess Plateau, China," Geomorphology, vol. 241, pp. 343-352, 2015.

[43] G. Zhao, G. M. Kondolf, X. Mu et al., "Sediment yield reduction associated with land use changes and check dams in a catchment of the Loess Plateau, China," CATENA, 2016.

[44] M. G. Kendall, Ed., Rank Correlation Methods, Charles Griffin, London, UK, 1975.

[45] H. B. Mann, "Non-parametric test against trend," Econometrika, vol. 13, no. 3, pp. 245-259, 1945.

[46] X. Mu, L. Zhang, T. R. McVicar, B. Chille, and P. Gau, "Analysis of the impact of conservation measures on stream flow regime in catchments of the Loess Plateau, China," Hydrological Processes, vol. 21, no. 16, pp. 2124-2134, 2007.

[47] S. Yue and C. Wang, "The Mann-Kendall test modified by effective sample size to detect trend in serially correlated 
hydrological series," Water Resources Management, vol. 18, no. 3, pp. 201-218, 2004.

[48] P. K. Sen, "Estimates of the regression coefficient based on Kendall's tau," Journal of the American Statistical Association, vol. 63, pp. 1379-1389, 1968.

[49] R. M. Hirsch, J. R. Slack, and R. A. Smith, "Techniques of trend analysis for monthly water quality data," Water Resources Research, vol. 18, no. 1, pp. 107-121, 1982.

[50] X. M. Mu, P. Gao, S. C. L. Ba, and X. P. Zhang, "Estimating the impact of conservation measures on stream-flow regime in catchments of the Loess Plateau, China," Advances in Earth Science, vol. 23, no. 4, pp. 382-389, 2008 (Chinese).

[51] M. Zheng, "Estimation of base flow using flow-sediment relationships in the Chinese loess plateau," Catena, vol. 125, pp. 129134, 2015.

[52] G. Verstraeten, J. Poesen, J. de Vente, and X. Koninckx, "Sediment yield variability in Spain: a quantitative and semiqualitative analysis using reservoir sedimentation rates," Geomorphology, vol. 50, no. 4, pp. 327-348, 2003.

[53] T. Ning, W. Liu, W. Lin, and X. Song, "NDVI variation and its responses to climate change on the northern Loess Plateau of China from 1998 to 2012," Advances in Meteorology, vol. 2015, Article ID 725427, 10 pages, 2015.

[54] X.-Z. Xu, H.-W. Zhang, and O. Zhang, "Development of check-dam systems in gullies on the Loess Plateau, China," Environmental Science and Policy, vol. 7, no. 2, pp. 79-86, 2004.

[55] D. C. Ran, Z. G. Zuo, and Z. P. Shangguan, "Analysis of sediment accretion dam damming and reducing grit in Yellow River Midstream heavy sediment and grit area," Journal of Hydraulic Engineering, vol. 37, pp. 433-450, 2006 (Chinese).

[56] C. Boix-Fayos, G. G. Barberá, F. López-Bermúdez, and V. M. Castillo, "Effects of check dams, reforestation and landuse changes on river channel morphology: case study of the Rogativa catchment (Murcia, Spain)," Geomorphology, vol. 91, no. 1-2, pp. 103-123, 2007.

[57] H. Y. Shi, T. J. Li, K. Wang, A. Zhang, G. Q. Wang, and X. D. Fu, "Physically based simulation of the streamflow decrease caused by sediment-trapping dams in the middle Yellow River," Hydrological Processes, vol. 30, no. 5, pp. 783-794, 2016.

[58] S. X. Cao, H. Ma, W. Yuan, and X. Wang, "Interaction of ecological and social factors affects vegetation recovery in China," Biological Conservation, vol. 180, pp. 270-277, 2014.

[59] C. X. Liu, T. Y. Zhao, X. L. Shi, and S. X. Cao, "Ecological restoration by afforestation may increase groundwater depth and create potentially large ecological and water opportunity costs in arid and semiarid China," Journal of Cleaner Production, 2016.

[60] S. X. Cao, T. Tian, L. Chen, X. Dong, X. X. Yu, and G. S. Wang, "Damage caused to the environment by reforestation policies in arid and semi-arid areas of China," Ambio, vol. 39, no. 4, pp. 279-283, 2010.

[61] S. X. Cao, L. Chen, D. Shankman, C. M. Wang, X. B. Wang, and H. Zhang, "Excessive reliance on afforestation in China's arid and semi-arid regions: lessons in ecological restoration," EarthScience Reviews, vol. 104, no. 4, pp. 240-245, 2011. 

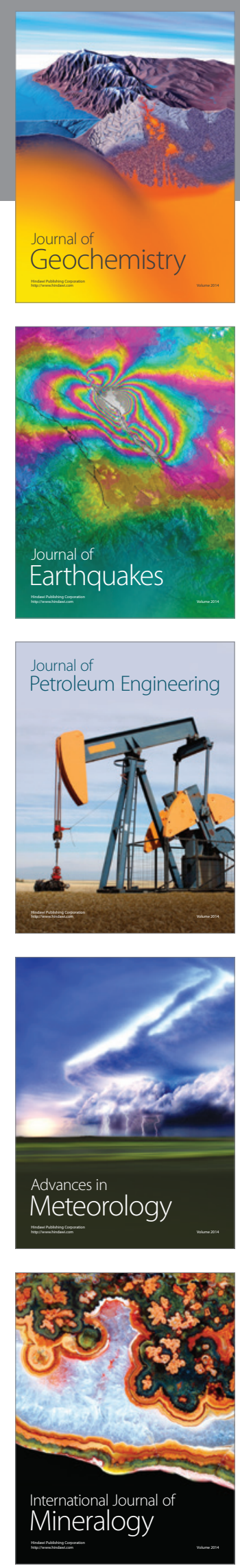
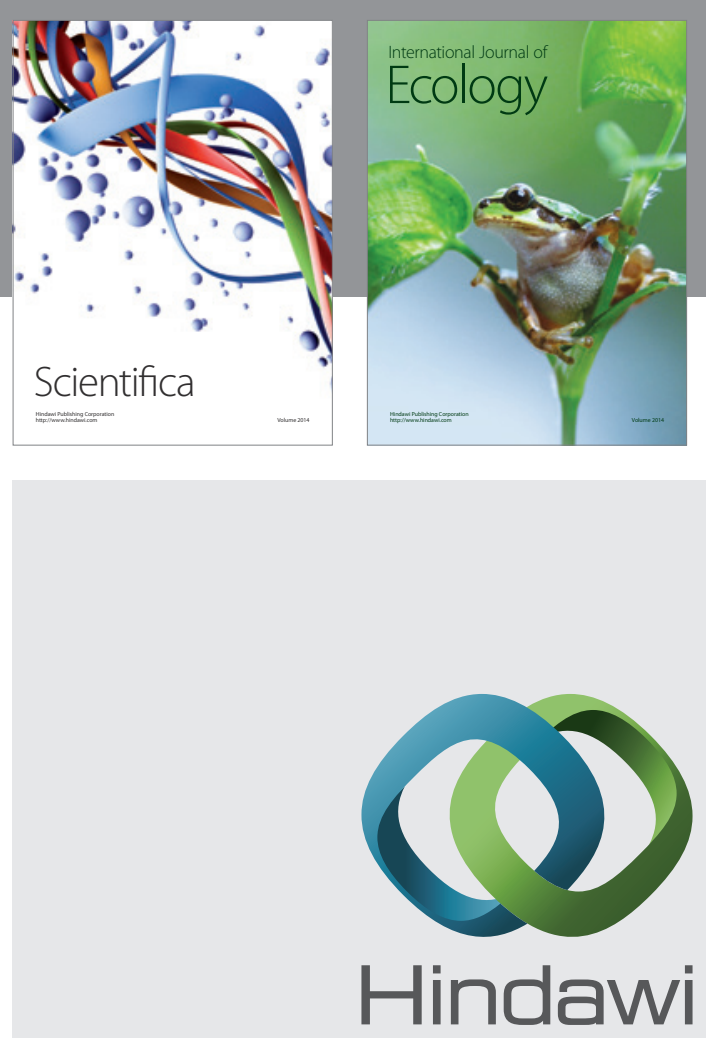

Submit your manuscripts at

http://www.hindawi.com
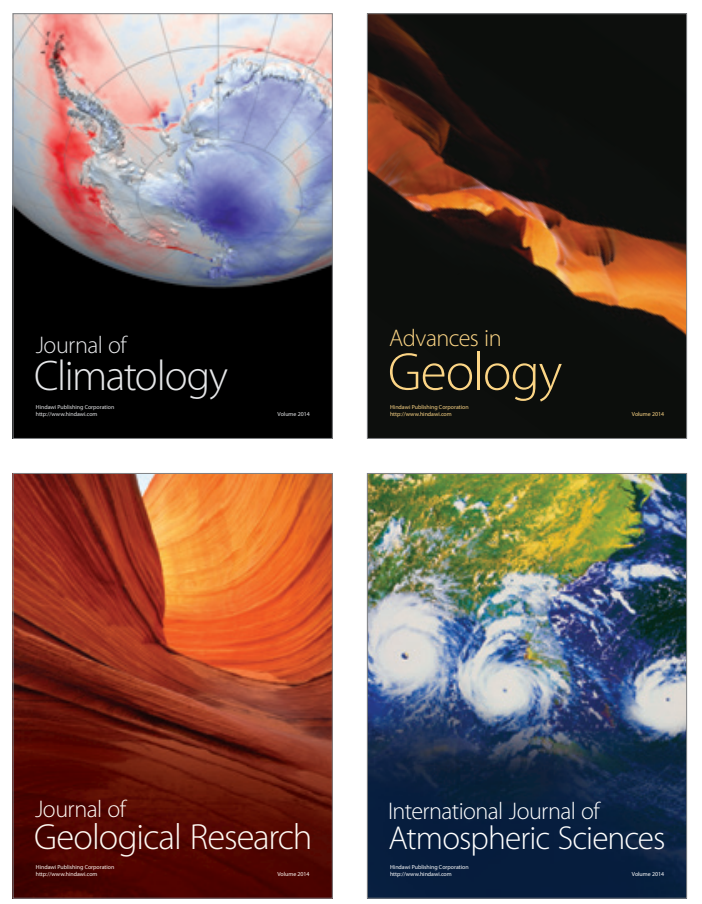

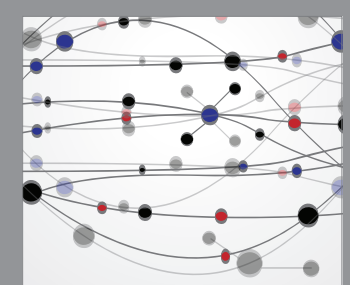

The Scientific

\section{World Journal}
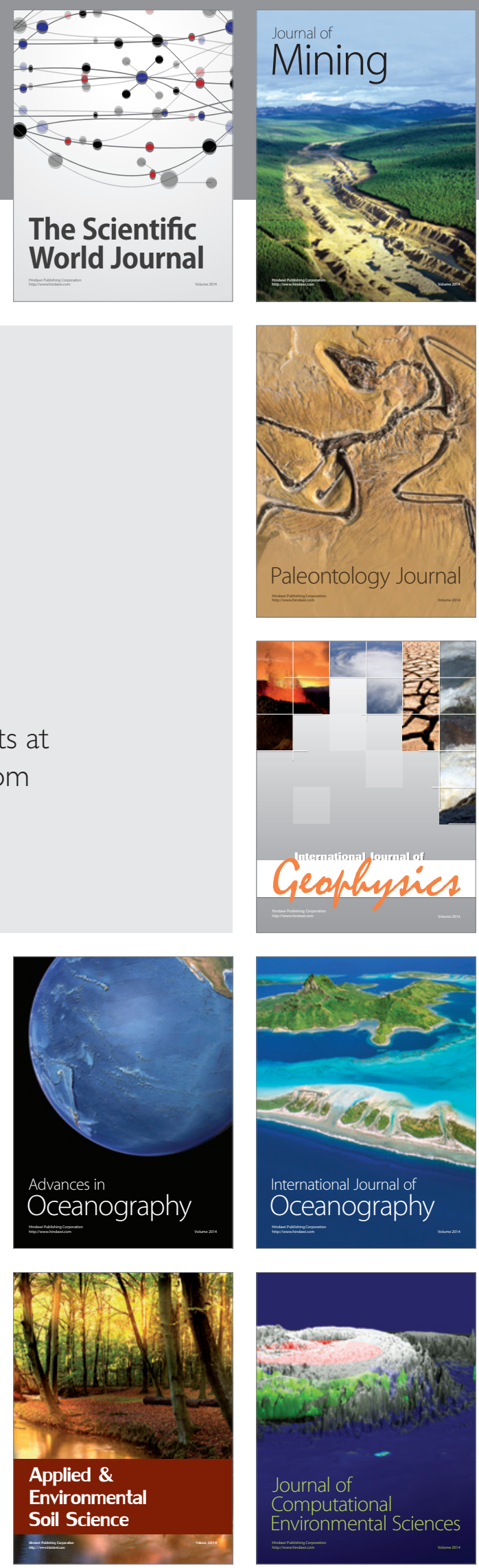